\title{
TEXTOS VISUALES EN ARQUEOLOGÍA
}

\author{
VISUAL TEXTS IN ARCHAEOLOGY
}

por

TOMÁS LLORET MARÍN ${ }^{1}$

A Ernesto Marín y Eulalia Delgado

RESUMEN El texto arqueológico, como cualquier otra expresión escrita, está construido de tal forma que impide el análisis de muchos de los aspectos visuales constitutivos de las culturas del pasado. En este trabajo, mediante la confrontación de texto e imagen, intentaremos dar algunas respuestas a esta insuficiencia visual del escrito.

\begin{abstract}
Archaeological description, as writings do, makes imposible the analysis of those aspects related to ancient cultures. This work, confronting text and image, will try to ilustrate the text "visual imbalance".
\end{abstract}

Palabras claves Imagen, investigación visual, texto y lenguaje.

Key words Image, visual research, text and language.

\section{INTRODUCCIÓN}

Quiero comenzar esta introducción, antes que nada, advirtiendo dos cuestiones. La primera hace referencia a la extensión desmedida de este apartado inicial. Es posible que una introducción tan extensa e inusual en Arqueología, aburra al lector más paciente o, incluso, haga desistir de su lectura al más curioso. Tal extensión, como podrán suponer, no es un capricho "snob" con el que intentar "fastidiar" al investigador que pudiera estar interesado en leer estas páginas (que por cierto, nunca dispone del tiempo suficiente para leer todo lo que quisiera), sino que, más bien, está motivada por una ausencia. Ausencia de Arqueología.

1. Grupo de Investigación "De la Turdetania a la Bética" (HUM-152). Departamento de Prehistoria y Arqueología de la Universidad de Sevilla. 
En estas páginas introductorias no se hace referencia a la Arqueología de una forma directa. Por lo que sé, SPAL aún sigue siendo una publicación seriada editada por arqueólogos y leída por arqueólogos, en la que se discute, principalmente de Arqueología. Por ello, cuando tengo que compartir con arqueólogos conocimientos que van más allá de los propios y exclusivos de nuestra disciplina, y que sobrepasan, en cierto modo, sus preocupaciones más inmediatas, necesito disponer de un generoso preámbulo en el que sentar ciertos precedentes que sirvan tanto de excusa inicial como de hilo argumental. La segunda cuestión sobre la que deseábamos llamar la atención es esta vez más generosa, y repercute en la totalidad del presente artículo. Quienes superen el reto inicial (concluir la lectura de la introducción), podrán comprobar cómo en el siguiente epígrafe, tampoco se reproduce un modelo tradicional de Arqueología. No se analizarán "científicamente" las piezas cerámicas de un importantísimo yacimiento, ni se abordarán complejísimos estudios estadísticos para demostrar que la "casualidad" no existe. Ni se estudiará la economía, ni la producción, ni un ídolo aparecido en una excavación de urgencia.

Aquí, más bien, pretendo mostrar que en ciertas ocasiones, lo textual -herramienta básica del historiadorno termina de satisfacer ciertos aspectos de la investigación arqueológica. Esta aseveración no puede ser planteada desde nuestra disciplina, por una serie de causas que podrán entender al concluir la lectura del artículo. Por lo tanto, para desvelar las limitaciones analíticas y comunicativas del texto, y para presentar un modelo alternativo que pueda cubrir algunas de estas carencias, debo iniciar esta introducción presentando ciertos documentos escritos que cumplan con algunos de estos requisitos; es decir, necesito exponer una serie de escritos que se encuentren en su límite expresivo, que pongan de manifiesto sus diversas imposibilidades. Así, página a página, capítulo a capítulo y libro a libro, en estos últimos años he ido extrayendo de algunas de las lecturas que caían en mis manos, breves pasajes que mostraban hasta qué punto el elemento visual se encuentra presente y enraizado incluso en lo textual, y cómo el texto por sí mismo, es incapaz de mostrar las últimas consecuencias de la experiencia visual. También tenía bastante claro que aquí no podía presentar ningún trabajo de carácter científico, pues en ellos, no se recogen los aspectos visuales que descubriremos en unos textos literarios "puros", sometidos sólo a las reglas propias de la literatura, sin ningún otro condicionante o distorsión. Veremos, paso a paso, cómo a partir de una recopilación de citas procedentes de novelas, la Arqueología puede tomar conciencia de algunas de sus limitaciones, e intentar en la medida de lo posible, subsanar tales deficiencias en el conocimiento científico.

Teniendo en cuenta lo inusitado de esta introducción, quisiera, antes de entrar de lleno en el análisis de los textos, comentar brevemente cómo están organizados y qué uso haré de ellos. Los pasajes escogidos de estas novelas (históricas, literatura de viajes, literatura clásica y terror) han sido agrupados en ocho grupos diferentes según el contenido al que aludían: lenguaje, reconocimiento del otro e identidad, kinésica, medio natural, arquitectura, contexto visual, objetos y cementerios. Cada cita viene precedida de una numeración $\left(n^{\circ}\right.$ de grupo $\mathrm{n}^{\circ}$ de orden) que la identifica para cuando sea necesario retomarla en el texto principal. Cada grupo concluye con una reflexión sobre el tema abordado y su correspondiente repercusión en el ámbito de lo visual, con este razonamiento pretendo que descubramos ciertas cuestiones posibles de la investigación arqueológica basada en imágenes, que hasta la fecha han sido olvidadas y obviadas, por múltiples razones que no vienen ahora al caso comentar, en beneficio de una supuesta "superioridad o eficacia científica" de la letra impresa. Estas reflexiones no son más que simples comentarios o anotaciones que aspiran sólo a convertirse en ideas introductorias. También, en el encabezamiento de cada grupo, a excepción del primero como lógicamente podrán comprender, se han incluido algunas figuras (fotografías) como ejercicio práctico. Mi intención, al introducir estas imágenes, es que el propio lector participe activamente en este trabajo y pueda experimentar las limitaciones textuales a las que nos referimos, intentando describir unívocamente por escrito la información que se presenta visualmente en cada fotografía. Sin ningún otro comentario que realizar comenzaré ahora con la enumeración: 
1) GRUPO PRIMERO: (lenguaje).

* 1.1) "Señores, Emperadores y Reyes, Duques y Marqueses, Condes, Caballeros y Burgueses, y todos aquellos que queráis conocer las diferentes razas de hombres y la variedad de las diversas regiones del mundo, e informaros de sus usos y costumbres: tomad este libro y hacéoslo leer; [...] que así os la contará nuestro libro con claridad y buen orden, todo ello como micer Marco Polo, sabio y noble ciudadano de Venecia, las describe porque las vio con sus propios ojos". Marco Polo. Libro de las maravillas. Editorial Anaya. Madrid. 1992:9.

*1.2) "Para hablar de forma inteligente sobre camellos con los bedu intenté aprender los diferentes términos que ellos utilizaban, y éstos, ya bastante numerosos en cualquier caso, tienden a variar entre las diversas tribus. Utilizaban varias palabras para el singular y el plural; tenían nombres diferentes para las distintas razas y colores, para camellos de montar y de pastoreo, y un término diferente, que variaba de acuerdo con el sexo del animal, para denominar un camello en cada año de su vida hasta que alcanzaba la plena madurez, asi como otros que se le aplicaban en cuanto que empezaba a hacerse viejo. Tenían vocablos para denominar una hembra estéril, y para una preñada o en época de criar, que variaba de nuevo de acuerdo con el tiempo que llevaba embarazada o lactando". Wilfred Thesiger. Arenas de Arabia. Editorial Península. Barcelona. 1998:109.

Podrán preguntarse qué tienen estos párrafos de especial con respecto a lo visual para que merezcan nuestra atención. El primero (1.1), es un alegato propagandístico que pretende incitar a la lectura del Libro de las Maravillas. Con el segundo de ellos (1.2), descubrimos que los antiguos habitantes de la actual Arabia, poseían un rico y extenso vocabulario ganadero acorde a su actividad preferencial: la cría de camellos. Pero no es este el sentido que le daremos a estos textos. Como todos sabemos y hemos experimentado en más de una ocasión, todo escrito puede ser entendido a diferentes niveles interpretativos. Superando este primer nivel informativo de interpretación, presentaré una segunda lectura de los mismos, con la intención de desvelar, por un lado, qué subyace bajo las líneas de estos breves pasajes que, ahora sí, estarán en conexión directa con la experiencia visual, y por otro lado, procuraré ofrecer indicios de la vinculación existente entre el lenguaje y la visión.

De la primera cita (1.1), he considerado necesario destacar dos ideas de suma importancia para el arqueólogo (en general para las Ciencias Humanísticas y Sociales) y que pasan completamente desapercibidas. En primer lugar, se recomienda "tomar este libro y hacérselo leer". Esto supone, o bien un gusto desmedido de la nobleza por la vida fácil, o bien, un analfabetismo generalizado de la población (fenómeno que se dilata en el tiempo hasta bien entrado el siglo XX, sólo para Europa). La mayor parte de la "historia" que nosotros aprendemos a través de los textos, fueron períodos de la existencia humana basados en la oralidad y en la visión como formas principales de comunicación. Sirva de ejemplo el que la Biblia, texto principal del cristianismo, no fue traducida al castellano hasta el siglo XVIII (Rodríguez 2002:12). Esto supuso no sólo una accesibilidad sumamente restringida a los Textos Sagrados, propiciada por la propia Iglesia Católica, sino que el contenido del dogma católico se expresaba icónicamente en iglesias y catedrales para un vulgo iletrado e "ignorante" (Bayard 1995). Si la Prehistoria, y la mayor parte de la Protohistoria y de la historia han sido dominios de la comunicación no textual, ¿por qué reducimos nuestras posibilidades de interpretación a las informaciones textuales?

La segunda idea que expongo aquí, incide de nuevo en este proceso, pero esta vez en un sentido inverso. Afirma Marco Polo en su introducción "que así os la contará nuestro libro con claridad y buen orden, todo ello como micer Marco Polo, sabio y noble ciudadano de Venecia, las describe porque las vio con sus propios ojos". Es decir, la experiencia y el conocimiento humano se confía generalmente, aún a pesar 
del analfabetismo, a un código textual escrito, sea éste o no el más adecuado para su correcta transmisión y comprensión. En este caso, la aventura de Marco Polo trasladada al papel implica un reduccionismo de su vivencia. ¿cómo distinguir la ciudad de Saciú de la de Cambaluc? ¿cuál era el paisaje, la fauna y la flora propias de la provincia de Adén? Si esta información es capaz de facilitárnosla porque la vio con sus propios ojos, sería más correcto que se presentase a nuestros ojos en forma de grabados e ilustraciones, en lugar de entregarse a nuestros ojos textualmente. Sólo de esta manera, su libro podrá contar con claridad y buen orden aquello que micer Marco Polo describe.

Con la segunda cita (1.2) nos encontramos ante un verdadero problema que concierne al propio origen y a la naturaleza del lenguaje humano. Este es un aspecto muy controvertido en la investigación linguística y, por supuesto, tengo que declarar aquí mi más absoluta ignorancia al respecto. No soy filólogo, ni pretendo asumir un papel que no me corresponde desempeñar, pero como historiador el lenguaje es parte constituyente de mi trabajo y me obliga a tomar una postura con respecto a la investigación que realizo, y así es precisamente como voy a proceder. Pues bien, en este texto como ya comprobamos, los bedu disponían de numerosos términos para designar los distintos tipos de camellos así como sus características, mientras que un occidental podría conceptualizar el mismo contenido bajo tres o cuatro vocablos diferentes a lo sumo. Si hoy dispusiésemos de la posibilidad de invitar a un bedu a nuestra civilización occidental sumamente tecnificada, le explicaríamos que tenemos al igual que ellos, numerosas variedades de "animales" que también nos transportan a través de nuestras extensas tierras. Unos son deportivos, otros son familiares, otros resisten mejor el trabajo duro y la carga, los hay diesel, turbodiesel, de gasolina con plomo y sin plomo, de color rojo, verde, azul o gris metalizado, con o sin airbag, de dos, cuatro, veinte años, e incluso recién nacidos que huelen diferente y son tratados con sumo cuidado. Y cada uno de ellos posee, igualmente, un nombre que los individualiza. Probablemente nuestro invitado experimentaría la misma confusión que padeció Wilfred Thesinger en su estancia entre las tribus de Arabia. Toda esta divagación me sirve para hacer notar la relación que existe entre el lenguaje, la visión, lo perceptual y la experiencia vital de cada cultura étnica. La necesidad de nominar aquello que se ve, aquello que pertenece a la esfera de nuestras vivencias, está en la base de una de las teorías sobre el origen del lenguaje, la teoría deíctica de Brugman, que ha sido fuertemente contestada, entre otros, por Bühler (1985:105). Sea como fuere el origen del lenguaje, la experiencia visual es, en la mayoría de las ocasiones, precursora de la experiencia nominal (Arnheim 1971).

2) Grupo Segundo: (reconocimiento del otro e identidad) (Fig. 1).

*2.1) "En la mañana llegaron los capangas. Venían montados y su cabalgata, apresurada y piafante, despertó a la Barbuda que gateó bajo la carpa para ver quiénes eran. En todas las viviendas de Ipupiará había curiosos; eran capangas y no cangaceiros ni guardias rurales por la manera como iban vestidos y porque, en las ancas de sus animales, se veía muy clara la misma marca de una hacienda". Mario Vargas Llosa. La guerra del fin del mundo. RBA Editores. Bárcelona. 1993:170.

* 2.2) “Un pastor nunca jamás abandonará su bastón, con el cual se apoya (con una pierna alzada), golpea a las ovejas, lucha con los gundahs (bandidos) o, tal como uno me demostró, quita a golpes los revólveres de las manos de los policías. Constituye un símbolo para los pastores, y ha dado su nombre a la maravillosa red sin la cual la hazaña de organizar la migración sería imposible". Robyn Davidson. Lugares desérticos. Editorial Planeta/Seix Barral. Barcelona.1997:176.

* 2.3) "Los bedu reconocen los camellos a más distancia de la que pueden distinguir a un ser humano. Al encontarse con un extraño pueden decir a qué tribu pertenece pornumerosos signos que sus expertos 
ojos perciben de inmediato: si lleva la cartuchera muy ceñida o colgando floja por delante, si lleva el turbante holgado o más apretado alrededor de la cabeza; las puntadas de su camisa, los pliegues del taparrabos, la funda de piel de su rifle, el dibujo de las alforjas, la forma en que ha enrollado la alfombra sobre ellas, hasta su manera de caminar: todo esto revela su identidad'. Wilfred Thesiger. Arenas de Arabia. Editorial Península. Barcelona. 1998:130.

* 2.4) "Cada muerte daba derecho al guerrero a llevar algún ornamento distintivo, una pluma de avestruz o peine en el cabello, un pendiente, brazalete o taparra-

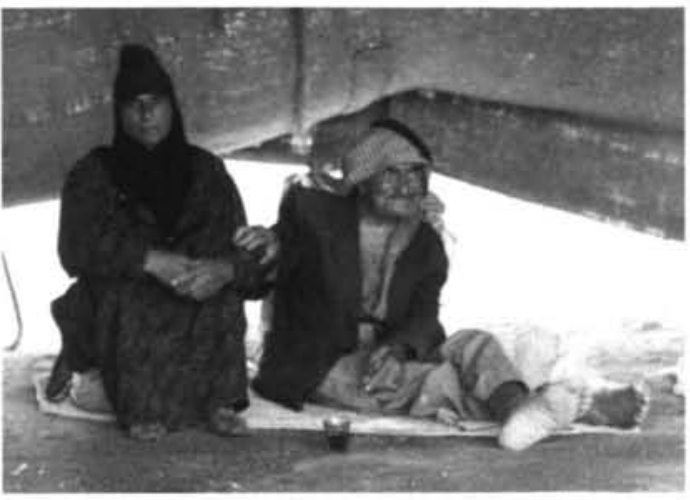

Fig. 1. Pastores nómadas (Siria) bos de colores. Se podía saber con una simple mirada cuántos hombres había matado cualquiera". Wilfred Thesinger. Arenas de Arabia. Editorial Península. Barcelona. 1998:34.

* 2.5) "Formaban una extraña pareja. Y la gente, principalmente los niños, se quedaban mirándolos con extrañeza, con indiscreta curiosidad. No comprendían cómo una doncella rica compartiera con un niño pobre. Clío ignoraba la insolencia que ello significaba en Roma. Porque la gente conjeturaba que el muchacho debía ser un pillete. De ser su paje iría vestido y adornado a la usanza". Alejandro Núñez. El denario de plata. Editorial Planeta. Barcelona. 1966:86.

* 2.6) "Apareció el molinero, con la ropa blanca de harina, y Rob distinguió a dos carpinteros por el polvo y las virutas de madera que cubrían sus túnicas y cabellos". Noah Gordon. El médico. Editorial Plural. Barcelona. 2000:52.

* 2.7) "Con su habilidad de mecánico, había construido una especie de monigote que al final se parecía bastante a Zósimo, con cabellos y barba largos e hirsutos, hechos con esparto ennegrecido, y dos piedras negras en lugar de los ojos. El retrato se presentaba endemoniado como aquél que representaba:

-Tendremos que pasar por lugares donde se hablan lenguas desconocidas-decía Ardzrouni-, y para preguntar si han visto pasar a Zósimo no nos quedará sino mostrar esta efigie". Umberto

Eco. Baudolino. Editorial Lumen. Barcelona. 2001:322.

* 2.8) "El lector sabrá muy bien, por vieja experiencia de todos conocida, que al entrar en un círculo de gente de otra raza todas las caras tienen un desesperante parecido y que es necesario hacer un penoso esfuerzo para distinguirlas entre sí. Es frecuente, en tales casos, recurrir, para establecer una distinción, a la diferencia de estaturas o a detalles de vestimenta". Franz Werfel. Los que no nacieron. Círculo de Lectores. Barcelona. 1993:54.

* 2.9) "Las jóvenes se pusieron enseguida de pie, prepararon víveres y engalanaron a la novia con joyas, vestidos y muchas cosas de gran valor cuya descripción es imposible". Anónimo. Las mil y una noches. Círculo de Lectores. Biblioteca Universal. Literaturas Orientales. Vol. III. Barcelona. 1998:347. 
* 2.10) "La senna no es una indumentaria tradicional yemenita. lo característico de esta parte de la península Arábiga son más bien los futah o mauwis, túnicas hasta la rodilla, y el 'abah, un chaleco sin mangas. Pero hoy los hombres llevan, sobre todo los viernes y días festivos, esa sencilla vestimenta blanca masculina, la mayoría de las veces con un ancho cinturón de cuero en el que tienen sitio la dschambija y la pistolera. Atado en la cabeza y cayendo sobre los hombros, completa el equipo el sumata, un gran paño de algodón finamente tejido. La forma y el color del tocado informan sobre el estatus social del que lo lleva. Por ejemplo, el verde está considerado el color de los jerifes, los descendientes directos del profeta. Todavía hasta principios del siglo pasado, en el Imperio Otomano, a judios y cristianos no se les permitía vestirse de verde"'. Michael Roes. Donde empieza el desierto. Editorial Edhasa. Barcelona. 1998:399-400.

En este segundo apartado, los procesos de comunicación visual que se establecen en el seno de los diferentes grupos culturales, se manifiestan de una manera evidente, el signo visual se emplea en el reconocimiento de categorías sociales y como medio de identificación y, por consiguiente, juega un papel de primer orden en la génesis de la "identidad visual" de un pueblo. Aún así, y a pesar de esta primera aproximación, todavía es posible profundizar más en la reflexión basándonos en estas citas. Las cinco primeras $(2.1 ; 2.2 ; 2.3$; 2.4 y 2.5) nos explican cuáles son los elementos decorativo-corporales que nos permiten extraer información de carácter social y así ordenar nuestro comportamiento. Es, por lo tanto, una información socialmente pactada y una forma directa y consciente de recibir unos datos que difícilmente esperaríamos recibir por escrito, puesto que las descripciones que han leído son aproximaciones orientativas, mas no definitivas.

Por el contrario, el punto 2.6., aún formando parte del mismo principio comunicativo ya comentado, recupera la información de una forma indirecta, no es un acto programado socialmente y mucho menos (en la mayoría de las ocasiones) consciente por parte del emisor. Es, por ello, una información de naturaleza casual y sometida a unas normas de codificación menos rígidas.

En el punto 2.7., la utilidad del lenguaje oral o escrito es insuficiente, y se han de buscar recursos que sustituyan dicha carencia. Aquí, el uso de la "efigie" presenta un claro paralelismo con el retrato o la fotografía actual. ¿Qué mejor recurso para preguntar por Zósimo que presentar al propio Zósimo? ¿cuántas palabras - aún en el supuesto caso de poder entenderse-deberían emplear Ardzrouni y sus compañeros para describir al perseguido? ¿sería una descripción oral unívoca?

En 2.8., hay una información visual inicial (las caras de personas de otra raza) que parece insuficiente para ser concluyente. Al igual que el lenguaje escrito, el visual emplea elementos de refuerzo en la información para evitar equívocos, en este caso fueron empleadas las diferencias de estatura y, de nuevo, la vestimenta.

La cita 2.9., siendo aparentemente la más sencilla de las diez que aquí se presentan, es para mí la más rica en contenido "visual", la más directa y la más clara. Sencillamente la descripción escrita es imposible porque el engalanado de la novia está concebido para ser contemplado, y no para ser constreñido a unas líneas que sólo empobrecerán expresivamente lo que de por sí es grande y de suma belleza.

Finalmente, el texto 2.10, que también contiene información sobre la indumentaria, nos plantea una nueva reflexión que va más allá de la mera decoración corporal, y que refuerza también las afirmaciones que planteé en el primer grupo. Comprobamos cómo varios términos (futah, 'abah o sumata) han de ser reforzados con nuevas descripciones, pues si no fuese así, nuestra comprensión de lo descrito sería nula. Estos casos nos demuestran que muchos términos necesitan de un conocimiento visual previo, para su correcta interpretación. Les pido que ejerciten este aspecto y eliminen las descripciones que acompañan a las tres palabras mencionadas, e intenten así imaginar la indumentaria del yemenita ${ }^{2}$.

2. Sobre el vestido y su significación, véase Squicciarino (1990). 
3) GruPo TERCERO: (Kinésica) (Fig 2).

* 3.1) "Hasta entonces no se dio cuenta Mino Jacobón de que el parto podría ser persona principal. Aunque el vestido era el vulgar atavio del viajero árabe y ningún signo exterior-fuera de la pulcritud-denunciaba su clase social, descubrían su alta calidad los ademanes, la expresión, las mismas palabras, todo ello entre indolente y medido". Alejandro Núñez. El hombre de Damasco. Editorial Planeta. Barcelona. 1966:14.

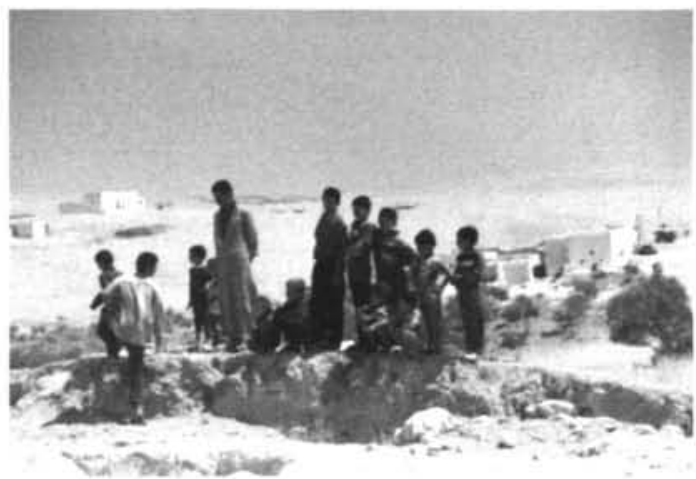

Fig. 2. Tell Jamís (Siria)

*3.2) "Una mujer mayor (viuda y por lo tanto vestida de un recatado marrón, con sólo algunos adornos de metal) hizo callar a todo el mundo y dirigió su atención hacia mí. No pensaba que yo pudiera comprender lo que ella decía, de manera que acercó mucho su cara hacia la mía y repitió las preguntas, en una especie de grito bien articulado. Pero el lenguaje de los gestos es universal, de manera que lentamente llegamos a comprendernos una a la otra. No, no tenía hijos. (Consternación y murmullos.) ¿Por qué? Pensé rápidamente. Porque mi marido murió joven. (Signos de compasión y asentimientos de cabezas.) ¿Padres? Ambos muertos. (Murmullo general.) ¿Y cuántos hermanos? Tengo una hermana. ¿Ningún hermano? Ningún hermano. (Sentimiento de tragedia en el aire.) ¿Y tiene tu hermana hijos? Cuatro hijas. Se produjo un respetuoso silencio en presencia de alguien tan perseguido por la mala fortuna, y mi interlocutora juntó las manos e indicó a un celestial Bhagwan, el cual, pareció sugerir, actuaba de misteriosas maneras". Robyn Davidson. Lugares desérticos. Editorial Planeta/Seix Barral. Barcelona. 1997:31.

* 3.3) "Llegamos a Baabara y nos fuimos directamente a casa del gigantesco Giga. Es una cosa cusiosa el que cuando uno no puede comunicarse a través del lenguaje, confía en unas capacidades menos dominantes, quizá prelinguales, para juzgar a las personas. Quizá sea algún intercambio químico, que los científicos no han descubierto todavía, lo que alienta la comunicación instantánea, o quizá en este caso tenía que ver con collares de oro. Fueran cuales fueran las razones, Giga y yo nos saludamos como miembros de una familia que no se ven desde hace mucho tiempo". Robyn Davidson. Lugares desérticos. Editorial Planeta/Seix Barral. Barcelona. 1997:88.

Una sonrisa, un ceño fruncido, así como miles de sutiles expresiones gestuales que el ojo apenas si tiene tiempo de captar, forman parte de la comunicación no verbal en todas las sociedades humanas (Hall 1973 y 1989; Davis, 1998; Knapp 1985; Poyatos 1994). Este aspecto del estudio antropológico y psicológico, englobado bajo el título de kinésica, constituye otro de los muchos matices de naturaleza visual que participan en la construcción de la cultura, y, por más que intentemos afinar en su descripción, no puede ser reflejado por el texto, pues es claramente de naturaleza visual.

4) Grupo CuARto: (Medio ambiente) (Fig 3).

* 4.1) "Alli estaba: azul y tranquilo, y le alegraba verlo después de tanto tiempo. Comprendió que en aquellos dos años había estado siempre echando algo de menos, y ahora sabía lo que era: ¡Horizontes...!' 


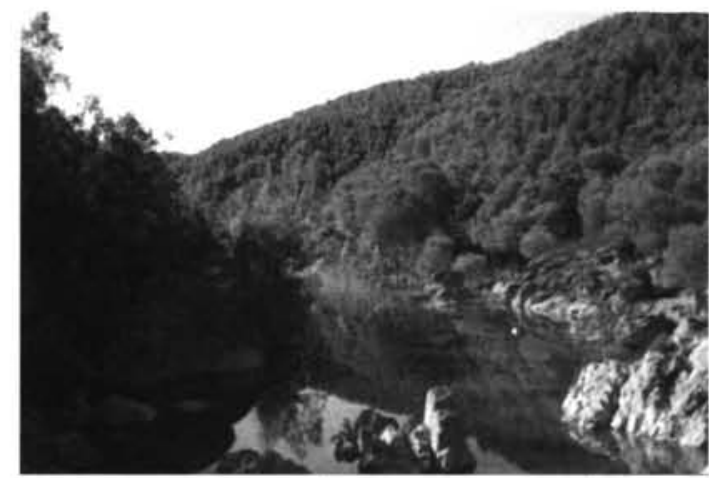

Fig. 3. Paisaje (Huelva)

Salvo en la laguna, en pocas partes de la selva podía encontrarse con un campo de visión que alcanzara más allá de los doscientos metros. El muro de vegetación cortaba la vista, y con el tiempo se perdía la noción de lejanía; se olvidaban las anchas llanuras; la inmensidad del océano y la línea del horizonte bajo la que se ocultaba el sol". Alberto Vázquez-Figueroa. Tierra virgen. Plaza y Janes Editores. Barcelona. 1986:153.

* 4.2) "Llegó al convencimiento de que tenía que abandonar de inmediato aquella abrumadora jungla y encontrar horizontes abiertos, o acabaría por volverse completamente loco, puesto que sentirse atrapado en un limitadísimo espacio en el que cada árbol era igual a otro árbol, cada hoja semejante a otra hoja, y cada liana tan atenazante como otra liana, sabiendo que por mucho que avanzara el paisaje continuaría siendo el mismo, constituía, sin duda, una prueba excesiva para alguien tan acostumbrado a la libertad como Cienfuegos". Alberto Vázquez-Figueroa. Cienfuegos II. Caribes. Plaza \& Janés editores. Barcelona. 1992: 105.

* 4.3) "Me consta que la conducta de los hombres es siempre la misma, pero aquí es distinto el paisaje, y en este caso ese "paisaje» influye de forma decisiva sobre esas conductas. Hay demasiadas tierras vírgenes, demasiados salvajes y demasiadas riquezas ocultas, y no resulta fácil distribuir todo ello con estricta justicia, recordando, ante todo, que Dios y la Corona deben ser siempre los más beneficiados". Alberto Vázquez-Figueroa. Cienfuegos V. Brazofuerte. Plaza \& Janés editores. Barcelona. 1992:187.

* 4.4) "Arena blanca, amarilla en el Djourab. Negra, rojiza, azulada en el Tibesti. Cristalina, gruesa, ondulante como olas, en el Ennedi.

Abrasadora al mediodía, cálida en la noche. Gélida al amanecer.

Un arenal de dunas es un gigantesco desierto estricto y vacío. Para ser llenado contigo mismo. Tus pensamientos. $Y$ tus sentimientos.

El horizonte inmenso, lejano, distante se pierde allá donde tus ojos no alcanzan más. Y aún más allá, se prolonga sin límites.

El entorno carece de otro adorno que la propia brutalidad de su belleza desnuda, muerta de vida animal o vegetal.

Piedras, rocas, arena y viento.

Donde intensa y profundamente te encuentras a ti mismo". Javier Nart. Viaje al desierto. Editorial Martínez Roca. Barcelona. 2000:85.

* 4.5) "Es difícil comprender por qué, pero igual que el sol aviva el espíritu y la lluvia lo entristece, el viento siempre lo inquieta y perturba". Matilde Asensi. Iacobus. Plaza \& Janés Editores. Barcelona. 2002:184.

Este cuarto grupo se inicia con tres citas de Vázquez-Figueroa (4.1;4.2; y 4.3), que como habrán comprobado son similares en contenido. Colocar a este excelente comunicador en primer lugar y presentando documentos análogos, tiene una explicación de índole argumental y temática. En el plano argumental, he 
pensado que una reiteración relacional podría facilitar aún más la comprensión de estos aspectos ${ }^{3}$. Con respecto al contenido temático he encontrado en sus numerosas novelas, y en definitiva en su pensamiento, una continuada labor de interrogación acerca del medio ambiente, del paisaje y su correspondiente influencia sobre el comportamiento individual y social. Preocupación que en términos arqueológicos y en lo que respecta al estudio cultural comparto con él. Pero, una vez más, el papel no es capaz de reproducir la enorme variabilidad del medio ambiente, sino más bien conceptualizaciones o categorizaciones del mismo. Las tres citas aludidas se unifican bajo un único concepto de "selva", con sus consiguientes vinculaciones de "espacio sin horizontes", "muro de vegetación que corta la vista", "tierra virgen", etc. Son por tanto, conceptos textuales apriorísticos, que se nos dan ya construidos, cerrados y limitados en sus posibilidades de interrogación, pues sobre ellos no podemos realizar nuevos análisis aparte de los que nos son dados, ya que el documento original (al ser una experiencia visual directa) no se nos entrega.

El epígrafe 4.4., contiene fundamentos similares a los correspondientes a los puntos precedentes, aunque como antítesis. Aquí "el horizonte inmenso, lejano, distante, que se pierde y prolonga sin límites" del desierto, se contrapone

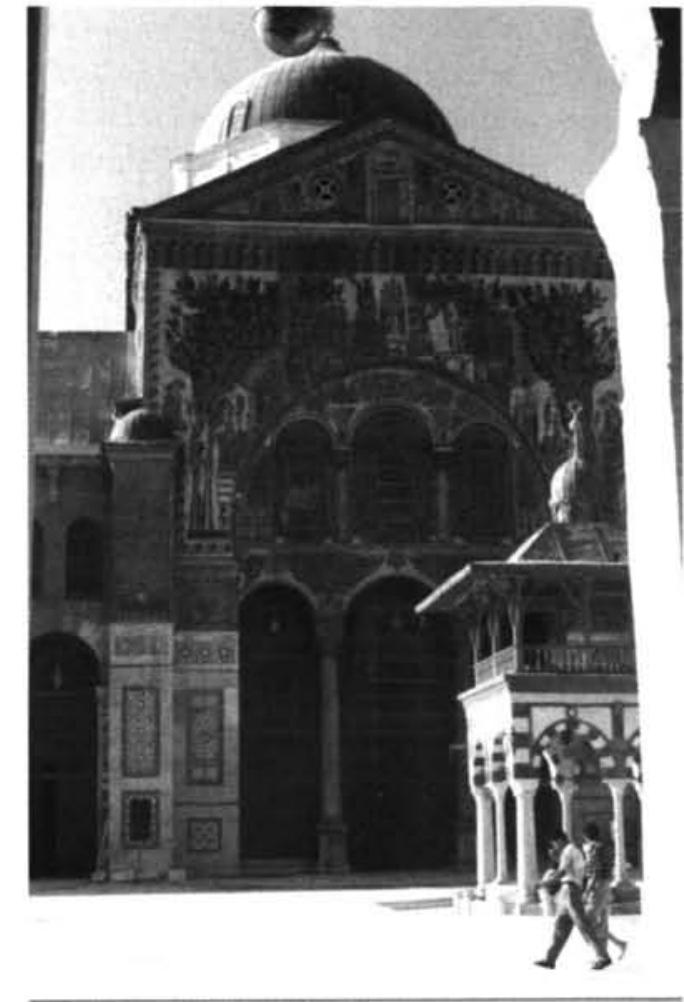

Fig. 4. Mezquita de Damasco a la visibilidad limitada de la jungla.

Por último, en el fragmento 4.5., Matilde Asensi nos habla del ya tan manido tema de la influencia climática sobre los sentimientos y el comportamiento de los individuos y de los pueblos. Las influencias climáticas y los fenómenos estacionales son fundamentalmente sensoriales, en el que la visión juega un papel primordial en el reconocimiento de tales expresiones. Los conceptos de "lluvia", "viento", "sol"o "primavera", se definen con iluminaciones, movimientos, transformaciones y elementos que les son propios y definidores.

\section{5) GruPo Quinto: (Arquitectura) (Fig.4).}

* 5.1) “»No tenía elección, general, no tenía elección, ¿lo comprendes? Si no quieres que vuelva la cigüeña, tienes que destruir el nido.

"Es cierto, he destruido una maravilla, pero ¿quién me impide reconstruir, llegado el momento, un edificio más grande y admirable aún? Pero entretanto he destruido también el símbolo de Persia y de sus reyes y he demostrado a los griegos y a los bárbaros de todo el mundo quién es el nuevo amo y señor; he demostrado que el pasado está muerto, es ceniza, y que nace una nueva era. Era hermoso, general, demasiado hermoso, y por eso era demasiado peligroso dejarlo en pie". Valerio Massimo Manfredi. Aléxandros. El confín del mundo. Editorial Grijalbo. Barcelona. 1999:149.

3. Con respecto a la línea de horizonte y a su visibilidad, Vázquez-Figueroa introduce reflexiones similares con respecto al desierto en "Tuareg" y "Arena y Viento". 
* 5.2) "Mengíbar y Cástulo habían sido arrasadas hasta los cimientos en castigo por su fidelidad a los Barca. Los legionarios de Escipión destruyeron las tumbas reales, entre ellas la de mi dulce Himilce a cuya estatua funeraria, que un esclavo denunció como representación de la esposa de Anibal, destrozaron el rostro a martillazos". Juan Eslava Galán. Yo, Anibal. Editorial Planeta. Barcelona. 1991:198.

* 5.3) "Con algún desconcierto ante tal comportamiento, fui arrastrado del pequeño vestíbulo de la entrada a una larga habitación que había al otro lado. Supuse que alguna vez había sido la casa de un comerciante de lanas que la había utilizado para almacenar fardos. Ciertamente era mucho más grande de lo que la fachada sugería (estos comerciantes siempre manifiestan ser pobres y no hacen pública su riqueza), y era un lugar agradable y luminoso gracias a que las anchas puertas estaban abiertas y dejaban entrar la luz de tal manera que, a pesar de la época del año, me quedé momentáneamente deslumbrado". Iain Pears. La cuarta verdad. Emecé editores. Barcelona. 2000:259.

* 5.4) “- Pero más adelante-aseguraba-, encontraremos sólo cristianos, aunque nestorianos.

- Bien-decía Baudolino-,si son nestorianos, son ya de la raza del Preste; pero de ahora en adelante antes de hablar prestemos atención, cuando entremos en una aldea, a si hay cruces y campanarios". Umberto Eco. Baudolino. Editorial Lumen. Barcelona. 2001:327.

* 5.5) "De seguro, ;oh Eumeo!, que es ésta la casa de Ulises, casa hermosa que bien se distingue aun estando entre muchas". Homero. Odisea. XVII, 264-265.

* 5.6) “No, no eran las gentes que se atropellaban en el foro, que gritaban, que se desgañitaban llamándose o insultándose u ofreciendo las innúmeras mercancías que llevaban en las amplias bandejas de madera. No eran aquellos hombres orgullosos, pendientes de los pliegues de la toga, seguidos por el grupo de clientes aduladores; no eran aquellos niños conducidos de la mano del criado lo que asustaba a Clío. Eran los mármoles, los bronces, las maderas policromadas, las piedras grises y rosadas, toda aquella materia exquisitamente tallada, labrada y pulimentada; toda aquella riqueza ornamental la que la cohibía. Era la grandeza arquitectónica, casi insultante, la que la atemorizaba, pues pensaba que aquellas gentes, las gentes a las que tendría que hablar, poseerían un corazón aún más duro y mejor organizado en la impasibilidad que los edificios". Alejandro Núñez. El denario de plata. Editorial Planeta. Barcelona. 1966:75.

* 5.7) "Aunque la iglesia de St. Asaph era pequeña, sus campanas eran grandes y retumbaban en la casa de la calle del Támesis, repicaban en vertiginoso concierto con los campanarios de las otras iglesias, comunicándose más eficazmente que un ejército de muecines. Las campanas llamaban a los fieles a la oración, las campanas estaban presentes en la consagración de la misa, las campanas advertían del toque de queda a los rezagados; las campanas anunciaban bodas y bautizos, y sonaban en un tañido fünebre y solemne por cada alma que pasaba a mejor vida, las campanas era la alerta de incendios y disturbios, daban la bienvenida a los visitantes distinguidos, sonaban para anunciar los días festivos y doblaban con tonos apagados para señalar los desastres. Para Mary, las campanas eran la ciudad.

Y odiaba las condenadas campanas". Noah Gordon. El médico. Editorial Plural. Barcelona. 2000:566-567.

* 5.8) " 'Saludos y buenos deseos a este palacio, al que los días han revestido de belleza!

Contiene toda clase de maravillas y prodigios, para cuya descripción es impotente la pluma". Anónimo. Las mil y una noches. Círculo de Lectores. Biblioteca Universal. Literaturas Orientales. Vol. II. Barcelona. 1998:52. 
* 5.9) "Los hebreos, estuvieran donde estuvieran y por encima de fronteras y culturas, formaban un pueblo ardorosamente unido por la Torá, y sus barrios (auténticas ciudades amuralladas dentro de las propias ciudades cristianas) les mantenían a salvo de las creencias, usanzas y conductas ajenas". Matilde Asensi. Iacobus. Plaza \& Janés Editores. Barcelona. 2002:188.

* 5.10) "Los españoles se aburren en los asedios largos, ya que carecen de la constancia necesaria para sostener el esfuerzo continuado. Por otra parte profesan una especie de miedo instintivo a las ciudades, tan acostumbrados están a la vida en míseros poblados o a la intemperie". Juan Eslava Galán. Yo, Anibal. Editorial Planeta. Barcelona. 1991:83.

* 5.11) “Cerró la tapa, se incorporó y extendió la vista por la calle tranquila y cuidada. Todo era armonía. Cada casa tenía un tejado de sombreadas tejas de color alquitrán, arena y melocotón, no tan severas como las tejas de color rojo anaranjado de muchas casas antiguas de California. Las paredes estucadas eran de color crema o de un color de la gama de los tonos pasteles coordinados que especificaban los "Convenios, Convenciones y Restricciones» que se adjuntaban con la concesión de las escrituras e hipotecas". Dean Koontz. Reino de tinieblas. Plaza \& Janés Editores. Barcelona. 2001:320.

Los dos primeros puntos (5.1 y 5.2) hacen mención a los procesos de destrucción de ciudades, estatuas y palacios tras su conquista militar, fenómeno generalizado no sólo en la antigüedad, sino también en nuestra contemporaneidad ${ }^{4}$. En el primero de ellos (5.1), se afirma haber destruido "el símbolo de Persia", mientras que en el segundo (5.2) se destruyeron los símbolos de la resistencia púnica frente a la república romana. Se destruye, se arrasa hasta los cimientos y se incendia hasta la completa desaparición física todo aquello que se "ve", pues estos símbolos se entienden y aprehenden visualmente.

Las tres siguientes citas (5.3., 5.4. y 5.5.) implican información captada visualmente del medio construido. El protagonista de La cuarta verdad (5.3) "supone" encontrarse en lo que otrora fue una casa de comerciantes, por determinados indicios que puede observar. En la siguiente referencia (5.4), "antes de hablar" es necesario "prestar atención a la presencia de cruces y campanarios", pues la información así obtenida permite inferir creencias religiosas cristianas y comportamientos asociados a ellas. En el punto 5.5., nos encontramos con un "se distingue", que es una transferencia al papel (textual) de un proceso analítico de carácter visual. Es decir, llegar a la conclusión de que la casa de Ulises es perfectamente diferenciable de las del entorno, implica una capacidad discriminadora e identificadora del ojo.

En 5.6., descubrimos como "los mármoles, los bronces, las maderas policromadas, las piedras grises y rosadas, toda aquella materia exquisitamente tallada, labrada y pulimentada", en definitiva "la grandeza arquitectónica", es apropiada e interiorizada por parte del hombre a través de la visión, y por medio de ésta se produce una influencia sobre su comportamiento, sus actitudes y sus creencias. Nunca un texto podrá sustituir la experiencia visual del medio construido. Titus Burckhardt (1981:11) ya afirmaba que la historia se veía en muchas ocasiones imposibilitada para captar la esencia de una civilización del pasado, y que este hecho se acentuaba especialmente cuando se contemplaba una imagen sagrada, un templo, una catedral o una mezquita.

El contenido del punto 5.7., es una variante arquitectónica, centrada esta vez en la campana, que resulta ser una experiencia auditiva y endovisual. Es decir, el tañido de la campana produce en Mary una recurrente evocación visuo-mental de la torre, que previamente había sido conocida mediante la visión.

4. Recuerden las imágenes ofrecidas por los medios de comunicación tras la invasión norteamericana de Irak y la caída del régimen de Hussein, en las que la eliminación de cualquier evidencia física del dictador (destrucción de retratos, efigies y estatuas) era una labor cotidiana y sistemática. 
En 5.8., nos encontramos de nuevo ante un pasaje de Las mil y una noches, que contiene una fórmula literaria ya empleada en términos muy similares, aunque aquí es la "pluma" la que se muestra "impotente" para la descripción arquitectónica.

La cita 5.9., nos da a conocer la existencia de barrios hebreos que son autónomos con respecto al resto de la ciudad, de ciudades incluidas en ciudades. Aparte del dato que se nos ofrece aquí sobre su perímetro amurallado, ¿podría el texto ofrecernos una "visión” adecuada sobre sus características formales, estéticas y normativas que fuese plenamente operativa para la investigación?

El fragmento 5.10., nos introduce la idea de "miedo instintivo a las ciudades". Muchos de los miedos creados culturalmente proceden de constructos mentales que no poseen una relación directa con la experiencia real (el coco con el que se asusta a los niños o la creencia en espíritus que amenazan o controlan nuestra vida), otros miedos sí proceden de una vivencia real, y se aprenden porque hay que enfrentarse a ellos. La muerte por ejemplo es uno de estos miedos, pues se contempla a diario. Con las ciudades ocurre igual, no es un miedo instintivo, es un miedo aprendido porque para temer a una ciudad primero hay que haberla experimentado, es necesario haberla contemplado, y no haberla comprendido.

El último punto (5.11), es casi un ejercicio práctico. Las "tejas de color alquitrán, arena y melocotón" y las "paredes de color crema o de un color de la gama de los tonos pasteles", nos dejan en una situación de indefinición visual, por más tejas y paredes que pensemos no podremos concretar la "calle tranquila y cuidada" de que se nos habla.

6) Grupo SeXto: (Contexto visual) (Fig. 5).

* 6.1) "A Eric Gill, el artista que esculpió este relieve, le costó mucho plasmar tal expresión. Estuvo trabajando sobre la pieza diecisiete largos años en un cobertizo de Ditchling, al pie de las colinas de South Downs. Enfundado en su guardapolvo, protegiéndose los ojos con unas gafas de gruesos cristales para que no le dañaran las esquirlas, fue cincelando los rasgos de Pilatos en piedra caliza de Hoptonwood. A la suave luz de Sussex, el rostro del romano pareció, al fin, decir todo lo que el escultor quería que dijese. Pero, una vez puesto en la catedral, «con el brillo del pavimento reflejándose en él [y] con el contraste de las sombras causadas por las luces eléctricas», resultó «otra cosa totalmente distinta». Gill le dijo a un amigo que la expresión del rostro había cambiado completamente, y que el resultado no le gustaba". Ann Wroe. Pilatos. Biografia de un hombre inventado. Tusquets Editores. Barcelona. 2000:206.

Un objeto puede resultar una cosa totalmente distinta según el entorno, el contexto situacional en el que se inserte. El contexto, por tanto, complementa la significación de la pieza que se analiza ${ }^{5}$. Pero es inalcanzable a través del papel, en él no podemos contemplar "los reflejos brillantes del pavimento", ni tampoco "el contraste de las sombras causadas por las luces eléctricas". El contexto de los objetos es, por tanto, un concepto visual de relaciones con respecto a otros objetos, edificios, paisajes y situaciones cromáticas y luminosas, en el que de nuevo se muestra impotente la pluma para su descripción.

7) GRUPO SÉPTIMO: (objetos) (Fig. 6).

* 7.1) "Ahora, a los treinta y siete años, descubría cosas de sí misma que habían afectado mucho su vida sin que ella las hubiese comprendido o aceptado, y muchas veces ni siquiera percibido, por ejemplo

5. Ya hice mención de este aspecto en un trabajo anterior, "Técnicas Audiovisuales en Arqueología". 


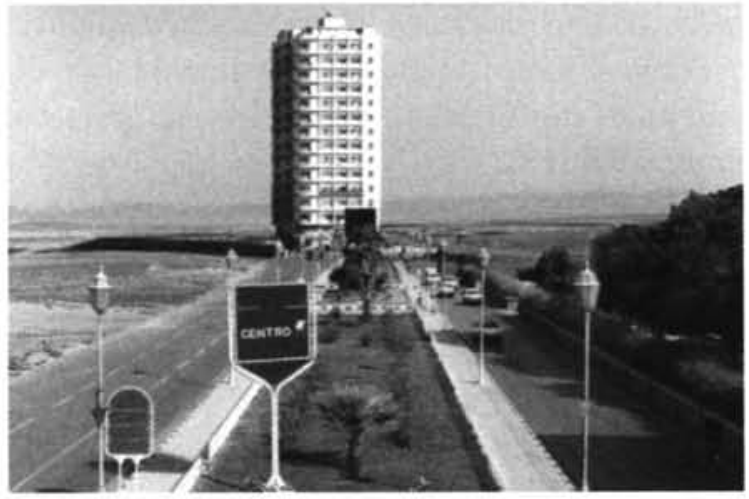

Fig. 5. ¿Ciudad o desierto? Un contexto imposible.

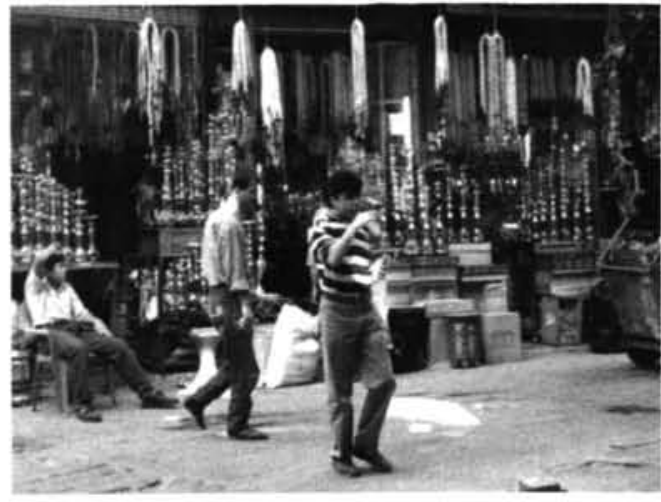

Fig. 6. Objetos en un zoco de Damasco.

el modo en que influían sobre ella los detalles menores, la fealdad o la belleza de los lugares o de los objetos que la rodeaban, la pena horrenda que le dieron aquellos carteles escritos a bolígrafo y pegados de cualquier modo sobre las puertas de los lavabos, lo que había de aceptación incondicional e inadvertida de los peores horrores y claudicaciones en el abandono de ciertos detalles, en la negligencia de las cosas diarias”. Antonio Muñoz Molina. Plenilunio. RBA Editores. Barcelona 1999:62.

* 7.2) "En Hispania acuñamos monedas con nuestra efigie, para que los indígenas nos respeten y teman como a criaturas divinas". Juan Eslava Galán. Yo, Anibal. Editorial Planeta. Barcelona. 1991:40.

* 7.3) "Si el horizonte australiano te invitaba a desprenderte de tu carga y a dirigirte a un punto que se desvanece, aquí las restricciones impuestas por el hombre dominaban cualquier impulso a moverse libremente. Perros y vallas, fuertes y muros defensivos, zinanas y verjas de clavos. Aros en la nariz, grilletes. Reglas y códigos que mantenían firmemente sujeta la estructura social. La forma del país venía definida por la salvaguarda de la propiedad'. Robyn Davidson. Lugares desérticos. Editorial Planeta/Seix Barral. Barcelona. 1997:189.

Las tres citas contenidas en este séptimo grupo las voy a analizar conjuntamente, ya que el principio que hace que el objeto no pueda ser definido por el escrito es que éste es "el principal responsable de la estética de la cotidianeidad" (Moles 1974:24). Así nos encontramos otra vez ante un concepto visual, el concepto estético de cada sociedad. Hay quienes pasan por la vida sin percatarse de este fenómeno, y hay quienes sólo a los "treinta y siete años" perciben cómo los objetos que rodean su existencia influencian sus valoraciones y estados anímicos. Pero "los objetos también son comunicación, son portadores de signos y un mediador universal" (Moles 1974:11,25), de esta manera "las monedas, las vallas, los muros, las zinanas y las verjas" forman parte del entorno cotidiano de nuestra existencia, y puesto que visualmente las percibimos, visualmente deben ser definidas, y en la medida de lo posible dentro de su contexto visual (grupo sexto).

8) GruPo octavo: (cementerios) (Fig. 7).

* 8.1) "De vez en cuando, se veían torres de piedra, precedidas por escaleras, erguidas sobre alturas aisladas: las torres del silencio, en las que los habitantes de aquellas tierras exponían sus muertos 


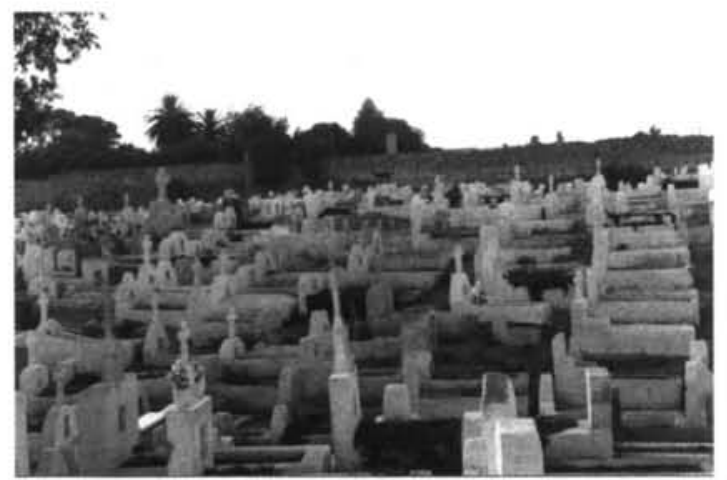

Fig. 7. Cementerio Municipal de Almería.

para que se disolvieran en la naturaleza, sin contaminar ni la tierra ni el fuego". Valerio Massimo Manfredi. Aléxandros. El confín del mundo. Editorial grijalbo. Barcelona. 1999:152.

* 8.2) "No la habían bautizado y lo hizo, llamándola María Eufrasia y rogando al Padre que se llevara a esa almita a Su gloria. Tomó juramento a la pareja y los mandó donde los Vilanova, para que su hija fuera enterrada. Por la escasez de madera, los entierros se habían convertido en un problema de Belo Monte. Lo recorrió un escalofrío. Era lo que más temía: su cuerpo sepultado en una fosa, sin nada que lo cubriera". Mario Vargas Llosa. La guerra del fin del mundo. RBA Editores. Barcelona.1993:224.

* 8.3) “Al llegar, joh mi rey!, haz memoria de mí, te lo ruego, no me dejes allí en soledad, sin sepulcro y sin llanto, no te vaya mi mal a traer el rencor de los dioses. Incinera mi cuerpo vestido de todas mis armas y levanta una tumba a la orilla del mar espumante que de mí, desgraciado, refiera a las gentes futuras; presta oído a mi súplica y alza en el túmulo el remo con que vivo remé compañero de todos los tuyos". Homero. Odisea. XI, 71-78.

* 8.4) “Rob J. encontró azuzenas junto al río y las plantó al pie de la tumba de Makwa. No era costumbre de los sauk marcar las tumbas con piedras, pero le pidió a Alden que cepillara una tabla de acacia, que no se pudriría. No parecía adecuado recordarla con palabras inglesas, así que le pidió a Alden que tallara en la madera los símbolos rúnicos que Makwa había llevado en el cuerpo, para indicar que ese lugar era de ella". Noah Gordon. Chaman. Ediciones B. Barcelona. 1994:323.

En 8.1., "se veían torres de piedra" que son identificadas no como campanarios, ni como torres-vigía, ni como bastiones defensivos, sino como "torres del silencio", estructuras arquitectónicas de la tradición funeraria zoroástrica. La identificación de una forma constructiva frente a distintas alternativas o posibilidades entre las que elegir es eminentemente un proceso visual en su génesis que posteriormente se nomina para su diferenciación referencial y conceptual.

En los puntos 8.2. y 8.3., el texto hace referencia a ciertos procedimientos funerarios que se traducen, en un caso, en una estructura construida ("el túmulo") y, en otro caso, en una norma ritual (enterrarse con "madera"). La muerte en ambos casos se deviene en angustia porque las expectativas sobre el funeral, los hábitos visuales que generan su repetición, pueden no cumplirse. La escasez de madera se convierte en un problema que puede llevar incluso a un sepelio del cadáver directamente in humus. La muerte por sorpresa, alejada del hogar, plantea al propio fallecido, la duda sobre su enterramiento. ¿Tendrá un túmulo adecuado que cumpla con su memoria?

El punto final con el que cerramos esta enumeración (8.4) alude a una estructura funeraria formada por una "tabla de acacia" en la que se han grabado unos "símbolos rúnicos", en este caso nos enfrentamos nuevamente a una intermediación del texto con respecto a la estructura funeraria, con lo que se produce una desvinculación entre la presencia física del material a estudiar y el investigador. 
Con el uso de unas citas literarias he planteado un problema de carácter histórico-metodológico, que podrá resolverse en la medida en que profundicemos en la naturaleza del texto escrito y de la imagen, para descubrir cómo ambas formas expresivas pueden llegar a suplementarse ${ }^{6}$, equilibrando las virtudes de ambos medios de conocimiento y los excesos de un uso preponderante por una de las partes. En este momento, por lo tanto, es necesario confrontar el binomio texto escrito-imagen para comprobar cómo cada una de estas expresiones orienta una forma de análisis diferente. Para analizar los límites narrativos del texto y de la imagen hay que cotejarlos, pero también hay que situarlos en una posición comunicativa comprometida. Es decir, para averiguar si la palabra o la imagen son respectivamente irreemplazables, tendremos que estudiar su grado de traductibilidad. Se suele decir que una imagen vale más que mil palabras, en tal caso, la traslación del contenido de la imagen a un código textual sería una tarea ardua y en muchas ocasiones frustrante. El contenido visual recogido en la figura 16, es difícilmente traducible en palabras de forma que se logre recopilar hasta el último detalle (decoraciones artísticas, iluminación, tonalidades, colores, estructura, materiales, distancias, líneas visuales). Se transforma, por tanto, bajo tres palabras ("interior de iglesia") en una convención textual, que guarda escasa relación con su referencia original. En este caso, la posibilidad textual de sintetizar tal experiencia visual, es relativamente baja y, por consiguiente, su grado de traductibilidad es también muy limitado. Por el contrario, también podemos hablar de palabras que valen más que mil imágenes. Imaginen la confusión expresiva que supondría comunicar el contenido de este trabajo exclusivamente con imágenes, o ¿Cómo podríamos dar a conocer determinados conceptos abstractos como "sinceridad" o "verdad", sino a través del lenguaje? ¿Cuántas secuencias de imágenes necesitaríamos para expresar tales ideas sin el uso de un símbolo? De nuevo, nos encontramos con que la traducción de determinadas palabras al código visual es escasamente operativa. Para situaciones como esta se acuñó la expresión de "al texto lo que es propio del texto, y a la imagen lo que es propio de la imagen". Si con el texto, el ser humano cubriese todas sus necesidades comunicativas, la imagen no tendría razón de ser, pero si existe es, precisamente, porque narra de una manera alternativa (Gubern 1987:52)

Convencidos ya de las respectivas diferencias expresivas y narrativas del escrito y de la imagen, no queda otra alternativa que preguntarnos cómo operan cada una de ellas y qué efectos producen en la investigación histórica, ya que el uso de la palabra o de la imagen promueve actitudes mentales muy diferenciadas. Veamos algunos de estos extremos:

1. La palabra denomina genéricamente, mientras que la imagen individualiza (Gubern 1987:51). El indeterminado "cuchillo de sílex" textual, se concreta, por ejemplo, en la fotografía, siendo entonces "este cuchillo de sílex" y no otro. La palabra al ser una abstracción y una convención que sirve para representar a todos los cuchillos de sílex del mundo, elimina la concreción de lo singular. Analizaré de una forma práctica las diferencias entre la generalización del texto y la individualización de la imagen en el primer ejemplo del siguiente apartado (punto 2).

2. De esta primera confrontación (generalidad frente a singularidad), se deriva la segunda diferencia entre el texto y la imagen. El texto escrito favorece la síntesis de un aspecto estudiado, mientras que la imagen tiende a promover el análisis del mismo ${ }^{7}$. La transformación de las fuentes materiales

6. Entiendo el término "suplementario" no como una dependencia de la imagen con respecto al texto, sino como una relación de igualdad, en la cual, la imagen completa la parte discursiva que le falta al texto y viceversa.

7. El texto es analítico en tanto en cuanto podemos volver sobre nuestra propia lectura y analizar o confrontar su contenido, internamente o con respecto a otros textos. Pero, al mismo tiempo es sintético, en el sentido que lo entiende Gubern, pues no presenta el todo por la reunión de sus partes, sino que olvida en su elaboración final dimensiones analizables de la cultura material, que desde este medio no podrán ser reincorporadas a la investigación. 
arqueológicas en narraciones textuales supone una "transustanciación", produce una verdadera "mutación de sustancia o de materia de la expresión" (Gubern 1987:52). Un yacimiento arqueológico cualquiera, una necrópolis, una vasija, un santuario o una estructura portuaria, terminarán transformando su cualidad visual originaria en un documento escrito más o menos elaborado. Aquello que inicialmente se entendía visualmente concluye codificado en un discurso verbal. Dicho discurso tiende a interpretar (transformar) las evidencias materiales en función de unos intereses argumentales o teóricos, obviando con la "transustanciación" otros elementos por la imposibilidad de registrar con palabras todo el contenido de las estructuras aludidas. La imagen es el único sistema actual de registro y transmisión de información que nos permite la intermediación expresiva más objetiva, puesto que entre el referente y la representación hay un menor grado de interpretación que con el texto ${ }^{8}$ (Moles 1974). La cualidad sintética del texto y la analítica de la imagen, las trataré en el segundo ejemplo del apartado 3.

3. El lenguaje escrito favorece el pensamiento lineal, mientras que el visual promueve un pensamiento global y tridimensional (Gubern 1987:51). La lectura y la escritura se producen en el tiempo y, por consiguiente son procesos secuenciales, que exigen un análisis gramático y lógico, favoreciendo de este modo el razonamiento deductivo. La imagen, por el contrario, se capta globalmente y facilita la conexión cognitiva de los elementos representados, facilitando en muchas ocasiones el pensamiento inductivo.

4. El lenguaje escrito privilegia los hechos, mientras que el visual privilegia el contexto. Es decir, la palabra explica o describe hechos y acontecimientos, por el contrario, la imagen muestra situaciones y relaciones entre los elementos exhibidos.

5. La alfabetización textual es aprendida desde la infancia, la visual es casi inexistente. A leer y escribir, así como a interpretar el contenido de un texto nos enseñan en los primeros años de nuestra vida. Posteriormente, el lenguaje propio de cada ciencia, se adquiere mediante un aprendizaje imitativo dentro de cada disciplina. Leer correctamente imágenes y ser capaces de construirlas, son enseñanzas tan específicas que sólo algunas disciplinas están en condiciones de impartirlas como asignaturas. La escasa formación icónica del investigador legitima su pensamiento, se es más científico si se escribe con letras que con píxeles.

Estas diferencias analizadas, que son tan elementales, bastan para darnos cuenta de que "el discurso no es tan sólo un medio utilizado por el investigador para exponer las explicaciones del pasado; la misma estructura discursiva utilizada -la narración- determina el modo de organizar el pasado y de producir su inteligibilidad" 9 . Inevitablemente, el lenguaje escrito influye en la forma en la que la Historia se construye, y puede, incluso, determinar lo que el científico hace (Gutiérrez 1998:24-26).

De los muchos aspectos constitutivos de la cultura que se elaboran, explican y transmiten de un modo visual, he repasado ocho de ellos en esta extensa introducción. Por ello, en el siguiente apartado me ocuparé principalmente de fundamentar el empleo del texto visual de forma práctica, justificando así mi proceder a lo largo de la introducción y explicando, al mismo tiempo, las implicaciones que dichos aspectos tienen para la investigación arqueológica.

8. En varias ocasiones (Lloret 1999, 2000 y e.p) he defendido el registro en vídeo de las excavaciones arqueológicas, puesto que hoy es posible que no atendamos a ciertos aspectos de la misma, que en un futuro pueden ser recuperados visualmente.

9. Según señala Vázquez García, citado por Morales (1995:183). 


\section{ALGUNOS EJEMPLOS}

No todos los casos visuales que descubrimos en las citas mostradas son aplicables a la Arqueología. Muchos de ellos son irrecuperables por su propia transitoriedad y, otros muchos, presentan una recuperación realmente dificultosa. Pero aún así, es posible rescatar e indagar en muchas de estas cuestiones. A continuación voy a presentar dos casos prácticos en los que la imagen resulta imprescindible para la investigación. Pasaremos así, de una discusión fundamentada en la retórica, a una argumentación basada en evidencias visuales, confirmando afirmativamente la hipótesis que habíamos planteado inicialmente. Es decir, demostraré que a través de la imagen el arqueólogo puede inferir información de carácter histórico, que no puede ser tratada ni encontrada en un escrito arqueológico.

\section{1) Ejemplo primero}

Retomamos de nuevo la figura 7, que fue presentada en el grupo octavo de la introducción como ejercicio práctico. Muestro en primer lugar esta figura para descubrir con ella cómo funciona la información visual y hasta qué punto es esencial en cualquier proceso de investigación histórico. Para lograr este objetivo les he mentido, tanto la descripción textual que acompañaba a esta imagen ("cementerio municipal de Almería"), así como la propia imagen han sido falseadas. Veamos, una a una, las razones de este proceder.

En primer lugar es necesario desvelar la influencia que sobre el lector ha tenido la descripción textual que acompañaba a la fotografía, pues así podremos explicar cómo se ha producido la lectura de la imagen. La descripción "cementerio municipal de Almería", nos ha proporcionado una información inicial sobre el contenido de la misma. La palabra "cementerio" nos ha proporcionado la información funcional y, siendo un término genérico, necesita de una nueva categorización para limitar su significado. En este caso, el primer apellido le ha correspondido al término "municipal", que nos ha proporcionado la información sobre su titularidad. Aún así, la indeterminación de la descripción es elevada, por lo que ha sido necesario añadir una nueva valoración, de "Almería", que define su localización geográfica. Ahora paseamos nuestra vista sobre la imagen, ya que los datos textuales nos han predispuesto a complementar la información disponible. Combinando la documentación textual con la visual, inferimos que el cementerio ha de ser cristiano, pues hay cruces sobre muchas de las tumbas, y si un cementerio es de titularidad pública, y al mismo tiempo está situado en Almería, lo más probable es que pertenezca a tal confesión religiosa. De esta forma, he demostrado varias de las aseveraciones que he defendido en estas páginas. Por una parte la suplementariedad del texto y la imagen en el conocimiento humano. Por la otra, cómo sobre una fotografía se ha extraído información, se ha realizado sobre una imagen una lectura visual, para completar unos datos previos de naturaleza textual. En ningún momento el apelativo de "cristiano" figuró textualmente en este escrito, ésta ha sido una información implementada desde una perspectiva visual.

En la figura 8 pueden observar, ya sin engaño, la imagen original antes de su manipulación, que corresponde al cementerio de la ciudad de Fez, en Marruecos. Sólo quienes hayan tenido un conocimiento visual del cementerio de Almería, previo a este ejemplo y a su categorización verbal mediante el empleo de un pie de fotografía, estarían en condiciones de desvelar el error introducido. También de este forma demostramos, tal como le ocurrió a Thesiger (1.2), que la experiencia visual directa, es en muchas ocasiones una experiencia previa a la "transustanciación" textual.

Dentro de esta reflexión, aún nos queda un último análisis. Si hubiese decidido presentar este mismo pie de fotografía con la figura 8 , en vez de haberlo hecho con la figura 7 , probablemente, las conclusiones habrían sido muy diferentes. En esta nueva situación la información textual habría entrado en conflicto con la visual. Posiblemente habríamos caído en la cuenta de que la orientación de las tumbas guarda un 


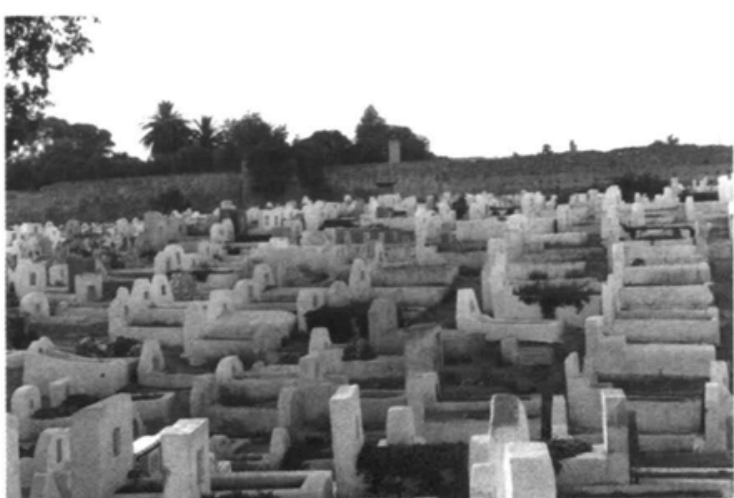

Fig. 8. Cementerio de Fez. (Marruecos).

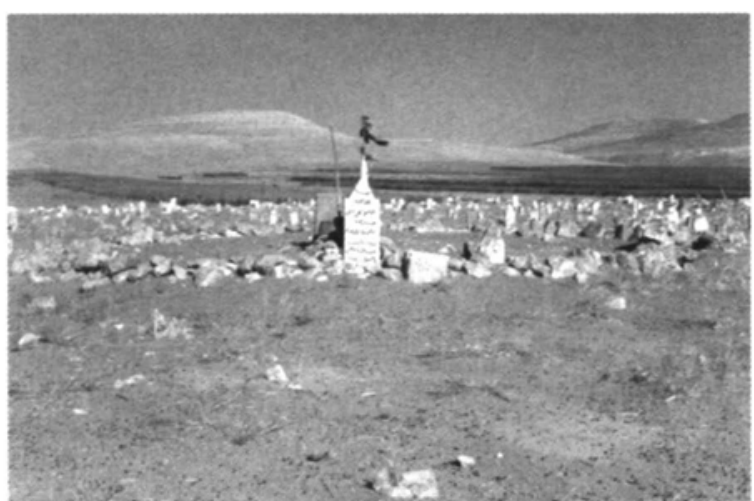

Fig. 9. Cementerio de Qara Quzaq (Siria).

patrón constante y regular, que se vincula a una prescripción islámica. Y sobre todo, habríamos notado la ausencia de una iconografía y simbologías propiamente cristianas (las cruces). De nuevo, comprobamos cómo la información visual puede llegar a formar juicios y criterios, que incluso pueden contradecir la información que se presenta textualmente. Aún en el ejemplo original, podríamos haber notado la discordancia entre el elemento cristiano y el islámico de la figura 7, pero se nos ha proporcionado un dato visual inicial (las cruces), que unido a la mayor veracidad concedida a la palabra (cementerio municipal de Almería) ha hecho que demos por buena la información facilitada. Un indicio más con el que ratificar nuestra escasa preparación para la lectura de documentos visuales (punto 5 del epígrafe 1).

Para seguir profundizando en la importancia de la información visual, y para conocer cómo la palabra es genérica y la imagen concreta, tendremos que centrarnos en una nueva imagen, la figura 9 . El contenido de ésta, quedaría textualmente categorizado como "cementerio islámico en Qara Quzaq (Siria)". Es esta una generalización tan ingrata, que anula por completo el medio ambiente (grupo cuarto), el contexto (grupo sexto), los objetos que conforman el cementerio y que determinan la estética de la cotidianeidad (grupo séptimo) y que sirven, asimismo, para establecer la identidad del grupo cultural (grupo segundo); elimina también el material empleado, así como el tratamiento espacial de cada uno de los elementos usados en la construcción del cementerio. Con esto no quiero decir que la palabra, con mayores o menores dificultades, no pueda describir estos aspectos, me refiero más bien a su imposibilidad de describirlas sin que sea posible confundirlo con cualquier otro cementerio islámico del mundo. La palabra puede describir las montañas situadas al fondo de la imagen, pero nunca nos dará a conocer sus tonalidades, sus alturas respectivas y su relación espacial y de escala con el cementerio. Tampoco conoceremos, por ejemplo, la posición exacta de cada piedra y su altura. Aspectos éstos que son únicos e irrepetibles, y son en definitiva los que le confieren la singularidad al registro fotográfico, y que jamás la palabra (generalización) podrá remedar.

A este primer ejemplo, que ahora concluye, se le puede objetar su mayor proximidad a la Antropología Visual que a la investigación arqueológica, pero con él hemos intentado ilustrar, antes que nada, la importancia de lo visual desde una perspectiva amplia y general. Transferir estas experiencias a la Arqueología, sólo necesitan de la voluntad necesaria para hacerlo y de la definición de un marco metodológico adecuado, combinando las nuevas tecnologías de la imagen (vídeo digital, fotografía digital y reconstrucción tridimensional). Este estudio, por consiguiente, no queda aquí sólo como caso práctico o ejemplo, sino que posee sus implicaciones en la investigación arqueológica. ¿Si nosotros hoy hemos extraído unos datos visuales de unas estructuras funerarias, no habrían obtenido nuestros antepasados, la mayoría analfabetos y con más necesidades de compensar esta deficiencia informativa, un conjunto mayor de datos sobre este mismo tipo de estructuras? Todos los procesos de asimilación o de diferenciación cultural, de reconocimiento étnico, 
religioso y territorial, basados en las necrópolis que estudia la Arqueología, pueden ser entendidos ahora como procesos visuales, y no textuales como viene ocurriendo hasta ahora.

\section{2) Ejemplo segundo}

Abordamos a continuación el estudio de un segundo caso con el que deseo comprobar dos cuestiones. Por una parte, quiero demostrar fehacientemente, y ya dentro de un contexto histórico, la utilidad de la imagen en la investigación Humanística. Por la otra, proporcionaré algunas reflexiones con las que explicar por qué el texto puede ser considerado como una síntesis de conocimientos, y por qué la imagen crea conocimiento histórico mediante procesos que son básicamente analíticos. Estas intenciones se concretan en un caso práctico, en el cual analizaré y confrontaré dos tipologías arquitectónicas de carácter religioso, la mezquita como edificio representativo del islamismo, y la iglesia como centro de culto del cristianismo. En un primer lugar, y basándome en un modelo hipotético, ensayaré el modo en el cual el texto debería recoger estas investigaciones, así como también plantearé las posibles imágenes que lo ilustrarían. Ya en segundo lugar, este presupuesto textual, nos situará en una posición óptima para introducir nuevas imágenes con las que demostrar la potencialidad analítica del medio icónico.

En el caso de enfrentarnos con diversos escritos que tratasen estos edificios religiosos, ¿qué nos encontraríamos en ellos? Probablemente, leeríamos una introducción para cada edificio con sus vicisitudes históricas, conoceríamos quién ordenó su construcción y quienes dirigieron las obras. También se nos ofrecerían diversas descripciones artísticas y arquitectónicas de los mismos, y algún que otro análisis de materiales. En una visión algo más profunda, podríamos encontrar algunas reflexiones que nos introdujesen en sus distintas funcionalidades y usos sociales, su integración urbanística y su valor político o religioso. Bajo una perspectiva exclusivamente arqueológica, los textos reflejarían las distintas fases arquitectónicas de los inmuebles, las sucesivas ampliaciones y reformas de los mismos, las técnicas constructivas empleadas y la procedencia de los materiales utilizados, sus posibles períodos de abandono o destrucción. El texto también asumiría una propuesta con la que dotar a cada uno de estos edificios de una lectura significativa a nivel territorial, social y religioso, relacionándolos con las noticias históricas textuales que conservamos sobre dichos períodos, en un intento de confirmarlas o refutarlas. Inevitablemente, estos textos habrían de acompañarse con diversas ilustraciones. Las primeras corresponderían a las plantas de los inmuebles. En la figura 10 presento la planta esquematizada de una mezquita bien conocida, la mezquita de Ibn Tulun, en El Cairo. En la figura 11, introduzco, en esta ocasión, la planta de la iglesia de San Ildefonso, de Sevilla. Las plantas arquitectónicas que en ellas se muestran, son un claro ejemplo del tratamiento visual que el arqueólogo realiza sobre los datos con los que trabaja. Esta forma de presentar la información nos sirve para conocer las dimensiones, escalas y posiciones de los elementos estudiados. Completando la serie de imágenes, se incluirían algunas otras con detalles parciales de los edificios y algunas perspectivas generales de los mismos, como fachadas o vistas aéreas.

Si aceptamos este modelo presentado como hipótesis para la reflexión, surge inmediatamente, una nueva cuestión a la que dar respuesta, ¿existe alguna subordinación o relación necesaria entre la investigación histórica y la forma en la que ésta se nos ofrece? En el texto se plasman los resultados de la investigación, no es, por tanto, en un sentido riguroso, el método de investigación ${ }^{10}$. Con esto no quiero decir que un texto se vea incapacitado para promover interrogaciones en el investigador, o que con él no podamos obtener

10. En un sentido estricto, sólo en las investigaciones filológico-arqueológicas, el análisis textual es analítico y en ellos coinciden análisis y síntesis. 


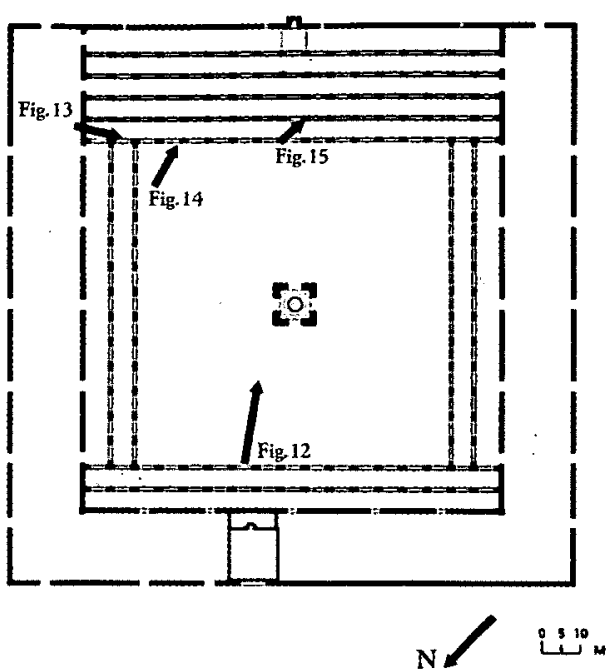

Fig. 10. Planta de la mezquita de Ibn Tulun.

un elevado porcentaje de nuestra información actual ${ }^{11}$. Más bien me inclino a afirmar que el texto constituye una meta, una conclusión, o un proceso final, sobre el cual se dirigen todas las miradas de la investigación (la ansiada meta de la publicación). Cada vez que un nuevo lector, que no ha tenido una participación directa en la investigación, revive mediante su lectura un documento en forma de artículo, monografía o memoria, está sujeto a tres procesos inherentes a lo textual, y que por consiguiente, son ineludibles: el selectivo, el interpretativo y el lineal.

$\mathrm{El}$ aspecto selectivo implica una elección y, al mismo tiempo, supone un rechazo. Si de una iglesia estudiamos sus técnicas constructivas, probablemente, no se producirá un análisis del programa iconográfico en ella contenido. Por lo tanto, en el escrito se reflejarán, con mayor o menor extensión, aspectos directamente relacionados con la edilicia del edificio, obviando las tallas, los cuadros, la decoración general y los retablos. Por el contrario, la imagen no discrimina inicialmente, a menos que se haga conscientemente, los elementos que debe registrar, y en una fotografía, encontramos reflejados conjuntamente tanto aspectos constructivos, como decorativos, de iluminación, o de distribución espacial. El aspecto interpretativo hace referencia al concepto de "transustanciación" ya aludido, en cuanto supone una transformación más o menos profunda de unas evidencias materiales. El investigador promueve la transformación de lo físico, lo concreto y lo objetivo, en tanto en cuanto posee una existencia material real, en un código textual que, lógicamente, también es selectivo. Es decir, la materialidad estudiada se reduce a categorías textuales que proceden de una terminología técnica, de la experiencia personal, o de simples valoraciones que en ningún modo son plenamente objetivas. Un ejemplo básico con el que ilustrar este aspecto, podría corresponder a una valoración

11. De ninguna forma niego la posibilidad analítica y de investigación del texto escrito, he defendido a lo largo de este artículo la suplementariedad de ambos sistemas cognitivos, y en mi ánimo sólo está presente el intentar demostrar cómo cada uno de estos medios expresivos permiten estudiar problemas históricos bajo perspectivas completamente diferentes... y suplementarias. 
de las dimensiones de la mezquita de Ibn Tulun. En el texto podríamos encontrar, a poco que apurásemos la búsqueda, afirmaciones tales como "...la grandiosa mezquita de Ibn Tulun, comenzó a construirse...". En la planta de la misma (figura 10), se muestra la escala gráfica del edificio, con lo cual la categorización verbal "grandiosa" es superflua, y como interpretación que es, puede producir una mayor grado de confusión e indeterminación que su correspondiente icónico ${ }^{12}$. El aspecto lineal del texto (punto 3 del epígrafe 2), nos viene a decir que todo escrito está estructurado temporalmente y su acceso debe producirse mediante distintas etapas comprensivas. José Luis Escacena (2000:37-46) se cuestionaba la causa por la cual los arqueólogos tendemos a dividir las culturas que estudiamos en tres estadios o fases evolutivas (por ejemplo, Bronce Final I, II y III). Sin dar la alternativa como cierta, insinuaba que la división tripartita de una cultura dada, podía fundamentarse en la propia biología animal (infancia/madurez/senectud). Más no nos hemos percatado aún de la influencia del texto en estas cuestiones. El escrito se estructura, igualmente, en tres fases, una introducción, un contenido o desarrollo y una conclusión. El texto escrito, por su propia dimensión temporal, predispone la mente del investigador, habituado a cumplimentar y transitar por dichas fases, a concebir el tiempo en un sentido lineal. No puede entenderse una fase B, si previamente no existe una fase A. El texto, por consiguiente, favorece la linealidad y la temporalidad de la historia ${ }^{13}$. Una imagen, sea cual sea, al captarse en un golpe de vista es, en este sentido, global y atemporal, no necesita de una transición previa para su entendimiento. Estos tres aspectos analizados son los que nos llevan a concluir que el texto escrito es "sintético". En tanto en'cuanto el texto supone una selección, una interpretación y una recuperación de los datos lineal y orientada, constituye un compendio de saberes y sobre todo una "síntesis", pues elimina otros muchos aspectos del documento original en función de determinados intereses de la investigación o de la accesibilidad a la información. Prueba de que el texto arqueológico es síntesis, la encontramos en las constantes visitas a los fondos de los museos, que se hacen necesarias, cada vez que un investigador quiere complementar su trabajo o iniciar nuevas pesquisas. En definitiva, el texto transmite mucha información y es de suma utilidad en la investigación histórica, pero en contadas ocasiones opera a un nivel analítico.

Corresponde ahora afrontar una reflexión paralela sobre las imágenes que acompañarían a estos supuestos textos. Estas figuras, como ya comentamos, consistirían en las plantas de los inmuebles y algunas otras en las que presentar aspectos parciales de los mismos o de conjunto. Es conveniente también preguntarnos sobre la función o funciones que cumplirían estas ilustraciones. Pero las bondades analíticas que he predicado para la imagen, no se encuentran contempladas en estas imaginarias publicaciones. Las figuras asociadas a estos textos son imágenes que cumplen esencialmente una función ostensiva (Gubern 1987:52), es decir, se presentan para confirmar que aquello que se manifiesta en el texto mediante palabras, es cierto y posee una existencia real. En este caso, las imágenes están sometidas y subordinadas al escrito, cumpliendo una simple labor pasiva de acompañamiento y confirmación. No funcionan activamente en la discusión textual y no implican una dimensión analítica que suplemente lo que el texto dice ${ }^{14}$.

La imagen activa y analítica supone en primer lugar una actitud del investigador, ya que al ser un documento menos interpretativo que el texto, nos permite estudiar otras dimensiones de la cultura objeto de estudio como si de un documento primario se tratase. Sobre las figuras 10 y 11 , podemos extraer otros datos mucho más enriquecedores que unas simples orientaciones o dimensiones. En estos edificios, y en

12. La planta de un edificio también es una interpretación, aunque la mediación existente entre el propio referente y la abstracción plástica supone una menor interferencia en el plano expresivo y documental, con respecto al texto.

13. En el fondo, y esto es una opinión completamente personal, creo que esta linealidad y temporalidad del texto ha favorecido la creencia en el progreso humano.

14. Obsérvese como las primeras nueve imágenes presentadas en este artículo, poseen una intencionalidad participativa y activa en el contexto del escrito. 


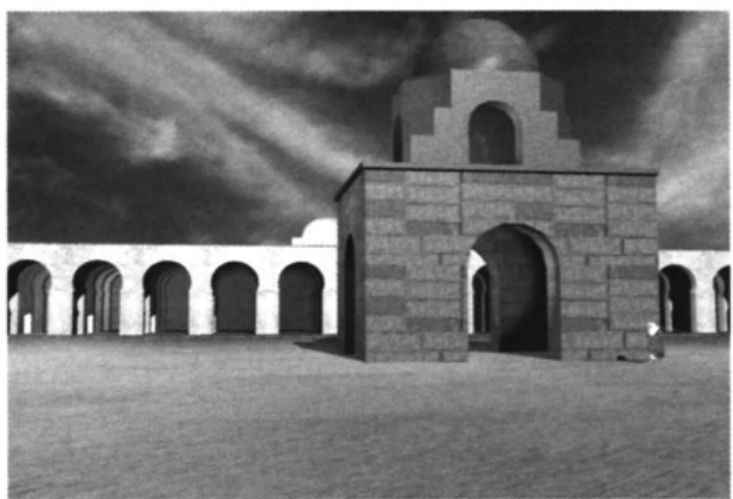

Fig. 12. Perspectiva del patio de la mezquita.

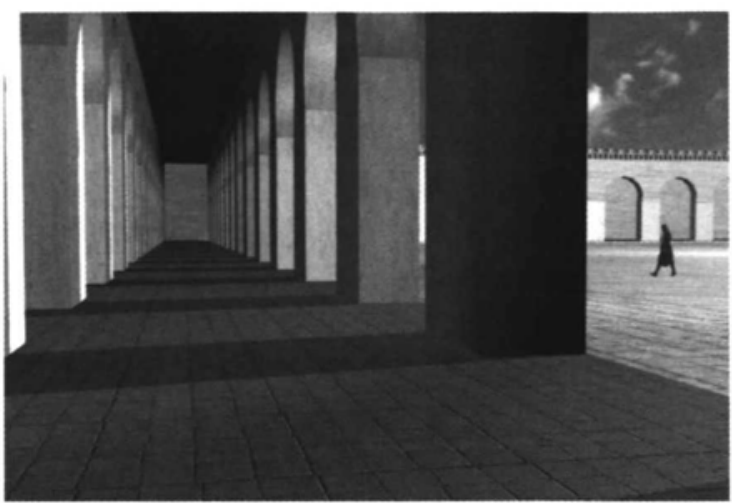

Fig. 13. Vista longitudinal de la sala de oración.

la dirección que indican las flechas, he situado varias cámaras con las que reproducir las perspectivas visuales del interior de los mismos desde dichas posiciones. La figura $12{ }^{15}$ reproduce una perspectiva de la mezquita desde el patio, poco después de ingresar al mismo por la puerta norte. La 13 muestra una vista longitudinal de las naves que componen la sala de oración, mientras que la figura 14 es una perspectiva transversal de la misma estancia. La última de las imágenes correspondientes a la mezquita (figura 15), reproduce el interior de la sala de oración, en dirección sur. Las figuras 16 y 17, por el contrario, muestran el interior de la Iglesia de San Ildefonso inmediatamente después de acceder al interior del templo. Tomando como base estas imágenes, aplicaremos sobre ellas un proceso analítico que nos permitirá formular una serie de preguntas que encontrarán sus oportunas respuestas en el propio documento. Estas conclusiones, adecuadamente integradas en un problema histórico, nos permiten comprender determinados procesos culturales desde una perspectiva completamente novedosa, pues, lógicamente habían sido obviadas por los textos.

En primer lugar, las dos plantas así como las figuras 12 y 16, nos sirven, tras una detallada observación, para comprender la primera diferencia a nivel visual existente entre ambos tipos de edificios. En ellas (figuras 10 y 12) se puede corroborar cómo el acceso a la mezquita desde la vía pública es gradual, mientras que en la iglesia (figuras 11 y 16) la transición entre espacio profano y sagrado es brusca. El patio de la mezquita, como espacio abierto, integra al cielo como parte constituyente de la construcción. Por el contrario, en el momento que un fiel cristiano entra en una iglesia, pierde todo contacto sensorial y visual con el exterior.

Cuando se ingresa en la iglesia (figura 16) el movimiento y la visión están condicionados por un eje axial que conecta la entrada con el ábside y el altar de celebración. Este efecto visual concentrado en un punto se ha reproducido en la figura 18. En el patio de la mezquita la atención visual está menos concentrada, y existen varios focos señalados en la figura 19. Traspasado el patio, y cumplidas las prescripciones de purificación, el musulmán se dirige a la sala de oración, situada al fondo del edificio. Allí, existen varias posibilidades para establecer más de una línea de atención visual (figuras 13,14 y 15), que se recogen en las figuras 20, 21 y 22. En las naves laterales de la iglesia, cuando éstas existen, se produce un proceso

15. Todas las imágenes correspondientes a esta mezquita son reconstrucciones tridimensionales realizadas según la información arquitectónica disponible. En ellas no he atendido más que a determinados aspectos arquitectónicos relacionados con el asunto que aquí analizo. Por lo tanto, no existe una intención por reproducir en estas reconstrucciones las decoraciones y los materiales del edificio tal como son realmente. 


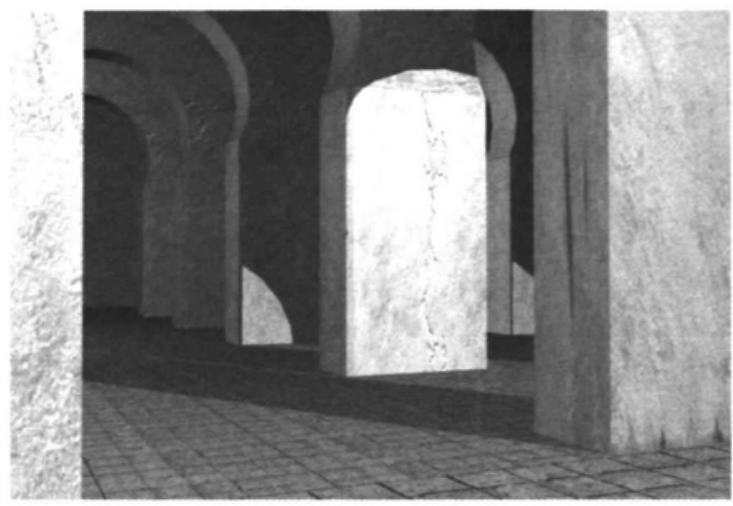

Fig. 14. Vista transversal de la sala de oración.

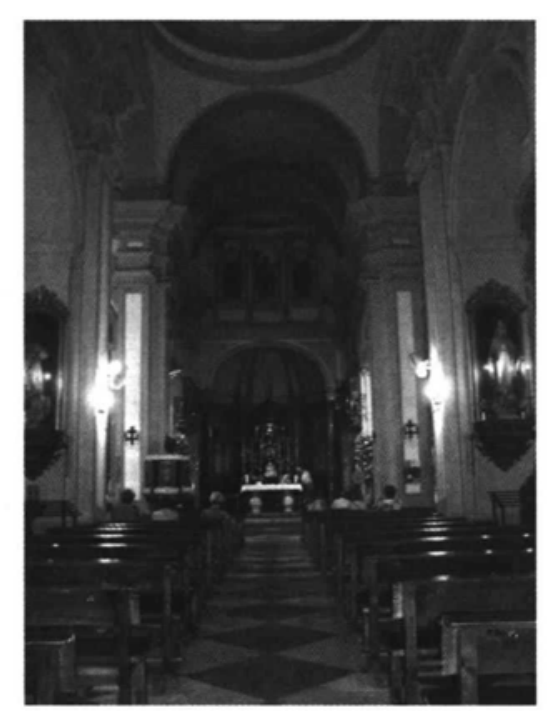

Fig. 16. Perspectiva de la nave central de la Iglesia de S. Ildefonso.

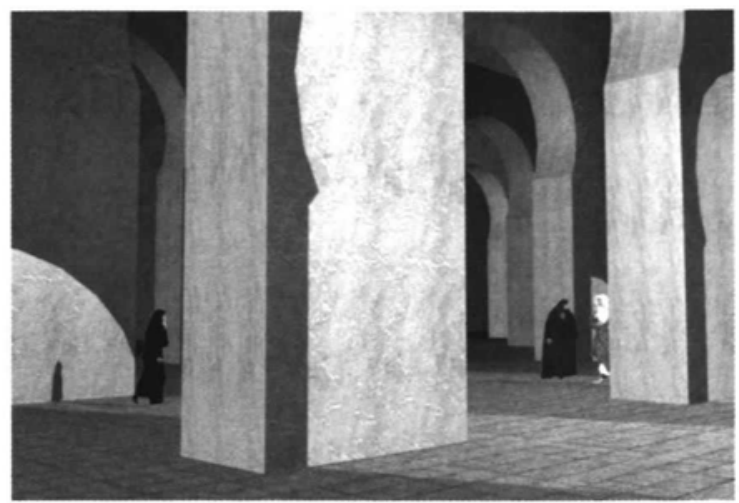

Fig. 15. Vista en dirección sur de la sala de oración.

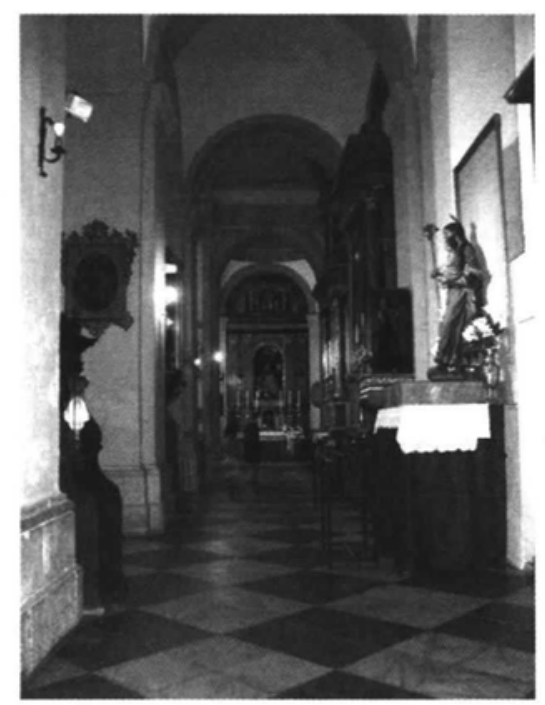

Fig. 17. Perspectiva de la nave lateral de la Iglesia de S. Ildefonso.

de acumulación de la atención focal, similar al estudiado en la nave principal (figuras 17 y 23). Estas cuestiones de naturaleza visual y de concentración de la atención, establecen actuaciones completamente diferenciadas. La atención única en un punto (sobre el oficiante) del cristianismo contrasta con una atención más dispersa de la mezquita, en ella no existe un punto, sino múltiples puntos de atención visual.

Cuando confrontamos textualmente los dos conceptos religiosos estudiados, aparecen siempre enfrentados por el dogma (la racionalidad del texto impreso). Creo que las diferencias entre ambas formas de entender la religiosidad, se basan mucho más en aspectos de carácter visual de lo que en un principio se piensa. El Islam y el Cristianismo creen profundamente ser posturas irreconciliables, pues el mensaje revelado que transmite cada una de estas religiones, en tanto en cuanto pretende ser la verdad única, les obliga a excluir cualquier visión alternativa. Lo que en un principio pudiera parecer un problema de doctrina (religiones que bajo un atento y profundo análisis comparativo proclaman unas creencias muy similares) pudiera resultar ser más bien un conflicto en la manera en la que se concreta el rito. Estos ritos, que desde la infancia hasta 


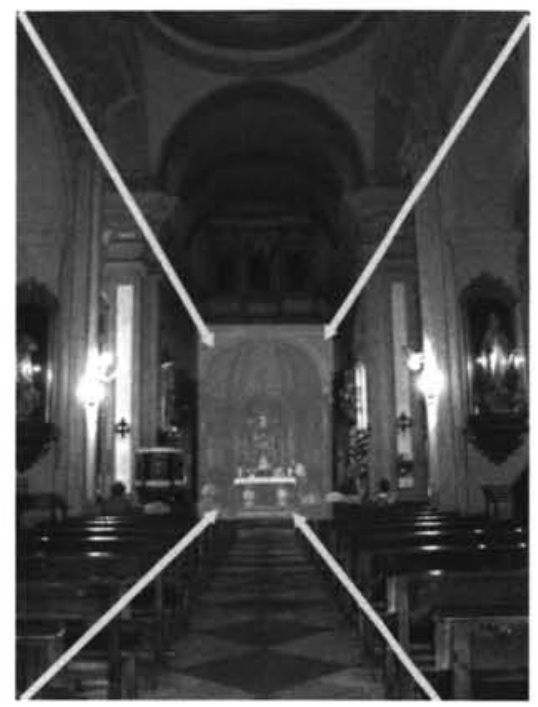

Fig. 18. Punto de atención visual central correspondiente a la figura 16.

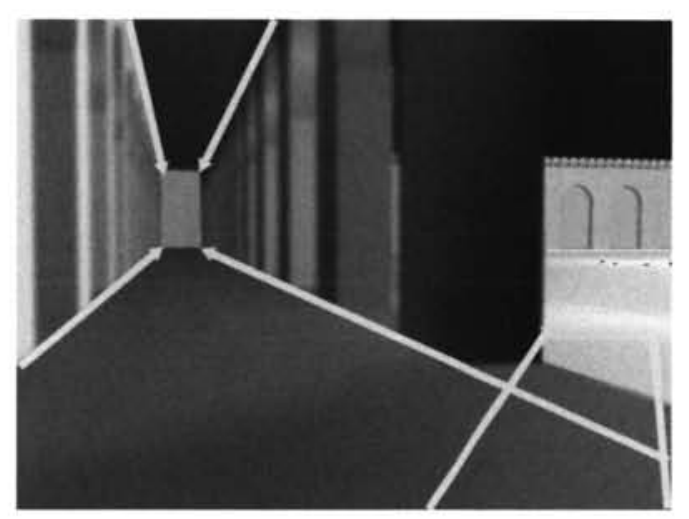

Fig. 20. Puntos de atención visual dispersos correspondientes a la figura 13 .

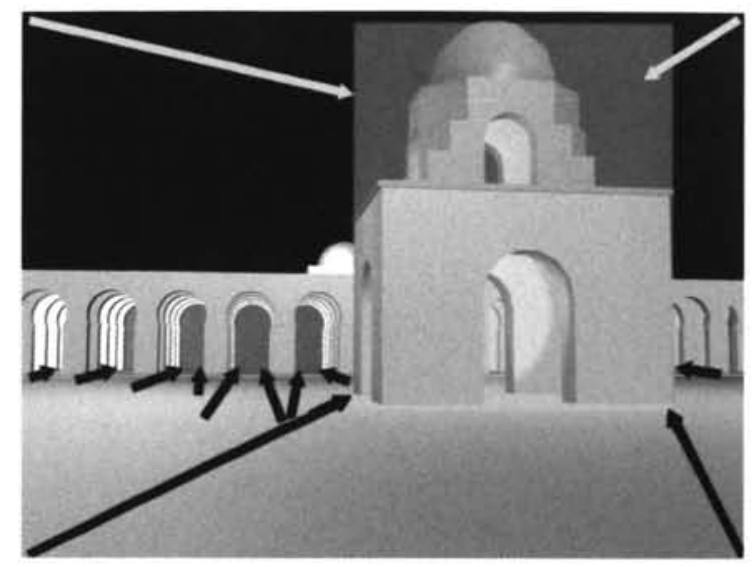

Fig. 19. Puntos de atención visual dispersos correspondientes a la figura 12 .

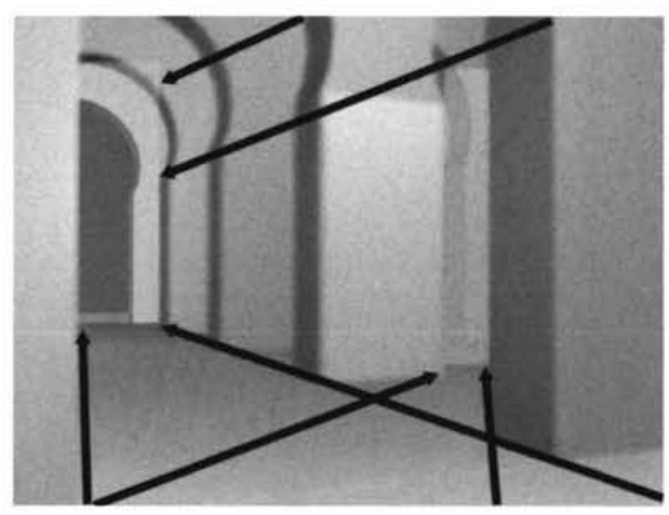

Fig. 21. Puntos de atención visual dispersos correspondientes a la figura 14 .

la muerte son constantemente repetidos, conforman un hábito visual en el creyente, que determina las expectativas que se han de cumplir. El musulmán entenderá el culto sin dirigir la mirada a un punto concreto, único y predeterminado, el cristiano, por el contrario, no podría asistir a su liturgia sin focalizar, sin dirigir y centrar su atención en un punto ya previsto. Si este punto no se diese, el cristiano no sabría qué hacer, se mostraría desorientado e impotente ante la deidad. A la postre, sin grandes ruidos pero con la constancia que otorga la cotidianeidad, será la incompatibilidad "visual" del culto, la que determine, en gran medida, las discrepancias respectivas con su oponente religioso ${ }^{16}$.

16. Sobre estos aspectos visuales en las mezquitas y en las iglesias, así como de su evolución histórica y arquitectónica, estamos actualmente elaborando un vídeo científico y otro documental, en colaboración con diversas instituciones. 


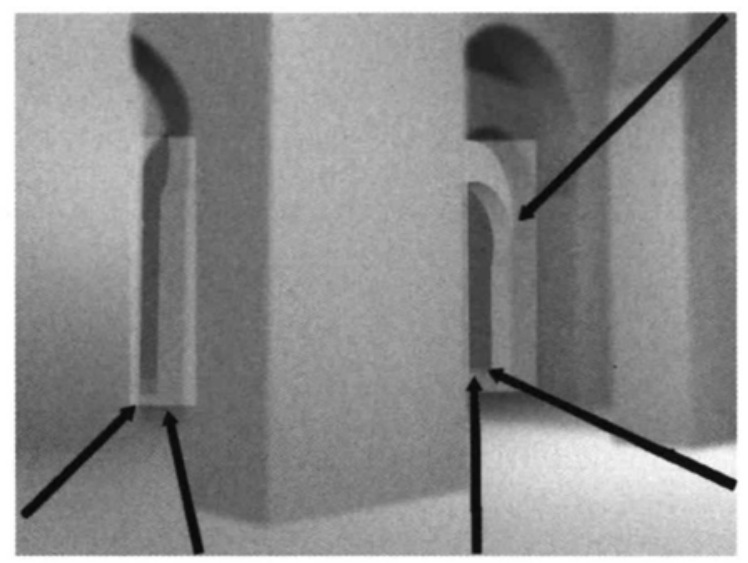

Fig. 22. Puntos de atención visual dispersos correspondiente a la figura 15 .

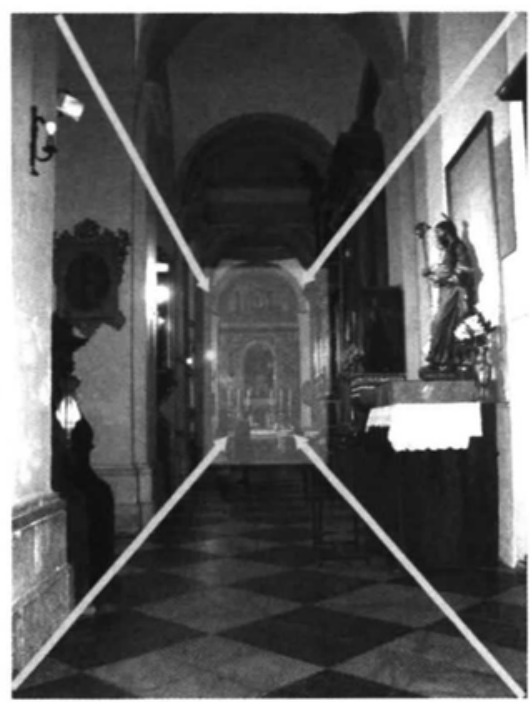

Fig. 23. Puntos de atención visual central correspondientes a la figura 17.

\section{CONCLUSIÓN}

El texto arqueológico se piensa a sí mismo en su propia universalidad e infalibilidad, más últimamente se comienza a plantear una visión complementaria (que no alternativa) a la Historia textual, cuya base se encuentra inmersa en la investigación con imágenes. La influencia del cine como medio divulgativo de la historia (Duplá e Iriarte 1990; Lillo 1994) y como medio de investigación (Rosenstone 1997) pueden ser un ejemplo de este nuevo movimiento. Las reflexiones, ya dentro de la Arqueología, que se están iniciando sobre la importancia de la imagen han sido sintetizadas y recogidas por Molyneaux (1997). Stephanie Moser (1998) indaga sobre la forma en la cual las creencias sobre el pasado se han ido plasmando a lo largo del tiempo en imágenes. En España no podemos pasar por alto los esfuerzos de Ricardo Olmos (iconografía-CSIC) y César Carreras (multimedia e internet-UOC) por integrar el estudio de la imagen como un elemento constituyente más de nuestra disciplina. Este trabajo, ha pretendido ser una modesta aportación más a esta nueva forma de entender la Arqueología. A lo largo de estas páginas, he intentado demostrar que, a través de las imágenes, se puede iniciar una verdadera investigación visual que suplemente la información y las posibilidades del escrito. La imagen, hoy, nos permite un grado de experimentación prácticamente ilimitado, con su uso podemos intentar recuperar los valores visuales del pasado, preguntándonos sobre sus significados y su influencia en la transformación cultural. Actualmente, estamos en condiciones de transferir buena parte de la información textual que genera la Arqueología, en "textos visuales", estudiando de este modo, una gran variedad de componentes culturales que hasta la fecha habían sido ignorados. Se abre así, un nuevo mundo casi inagotable en la investigación arqueológica, que denomino bajo el término de "Arqueología Audiovisual" ${ }^{17}$.

17. La "Arqueología Audiovisual" ha sido definida, por el momento, sólo como técnica audiovisual que engloba y estudia cualquier expresión icónica, ya sea ésta fija (fotografía, dibujo, imagen sintética) o en movimiento (vídeo, cine o multimedia). Actualmente èstamos trabajando, con esta base técnica, en la definición metodológica y teórica de la "Arqueología Audiovisual". 


\section{AGRADECIMIENTOS}

Agradezco a Enrique García Vargas las observaciones que hizo sobre el borrador del presente trabajo, pues gracias a ellas se pudo mejorar ostensiblemente su presentación, su coherencia interna y su inteligibilidad. Agradezco, igualmente, a Ana Porras Crevillent, la traducción del resumen castellano al inglés. Y, finalmente, agradezco la inspiración de todos y cada uno de los escritores aquí comentados, y a sus editores, sin los cuales este artículo no habría visto nunca la luz.

\section{BIBLIOGRAFÍA}

ARNHEIM, R. (1971): El pensamiento visual. Editorial Universitaria de Buenos Aires. Buenos Aires.

BAYARD, J.P.(1995): El secreto de las catedrales. Del simbolismo medieval a su realización arquitectónica. Tikal Ediciones. Gerona.

BÜHLER, K. (1985): Teoría del lenguaje. Alianza Editorial. Madrid.

BURCKHARDT, T. (1981): La civilización hispano-árabe. Alianza Editorial. Madrid.

DAVIS, F. (1998): La comunicación no verbal. Alianza Editorial. Madrid.

DUPLÁ, A. e IRIARTE, A. (1990): El cine y el mundo antiguo. Servicio Editorial Universidad del País Vasco. Bilbao.

ESCACENA, J.L. (2000): La Arqueología Protohistórica del sur de la Península lbérica. Historia de un río revuelto. Editorial Síntesis. Madrid.

GUTIERREZ, B.M. (1998): La ciencia empieza en la palabra: análisis e historia del lenguaje científico. Editorial Península. Barcelona.

HALL, E. T. (1973): La dimensión oculta. Enfoque antropológico del uso del espacio. Instituto de Estudios de Administración Local. Madrid. (1989): El lenguaje silencioso. Alianza Editorial. Madrid.

KNAPP, M. L. (1985): La comunicación no verbal. El cuerpo y el entorno. Editorial Paidós. Barcelona. LILLO, F. (1994): El cine de romanos y su aplicación didáctica. Ediciones Clásicas. Madrid.

LLORET, T. (1999): "Una nueva forma de ver la Arqueología: Arqueología Audiovisual", Arqueoweb l(3), (on line).

(2000): La Arqueología Audiovisual como técnica de conservación y difusión del Patrimonio. Espacio y Tiempo. Revista de Ciencias Humanas, 14: 171-178.

(2003): Técnicas audiovisuales en Arqueología. Una introducción para su aplicación práctica. Servicio de Publicaciones de la Universidad de Sevilla. Sevilla.

MOLES, A. (1974): Teoría de los objetos. Editorial Gustavo Gili. Barcelona.

MOLYNEAUX, B. L. (ed) (1997): The cultural life of images. Visual representation in archaeology. Rotledge. Londres y Nueva York.

MORALES, A. (1995): "Paul Ricoeur y la narración histórica", en Barros, C. (ed): Historia a Debate. Otros enfoques. Tomo III. La Coruña.

MOSER, S. (1998): Ancestral images. The iconography of human origins. Sutton Publishing. Gloucestershire. POYATOS, F. (1994): La comunicación no verbal. Editorial Istmo. Madrid. (3 Vols)

RODRÍGUEZ, J. (2002): Mentiras fundamentales de la Iglesia Católica. Editorial Suma de Letras. Madrid. ROSENSTONE, R. A. (1997): El pasado en imágenes. El desafío del cine a nuestra idea de historia. Editorial Ariel. Barcelona.

SQUICCIARINO, N. (1990): El vestido habla: consideraciones psico-sociológicas sobre la indumentaria. Editorial Cátedra. Madrid. 